\title{
THE EFFECT OF WATERING REGIMES AND BIO AND CHEMICAL TREATMENTS ON FLOWERING OF EUPHORBIA MILII VAR. LONGIFOLIA PLANTS
}

\author{
Azza M. Abd-Elmoneim*, Nermeen E. Abdul-Moneem* and A. K. Ibrahim ${ }^{* *}$ \\ * Ornamental Plants and Landscape Gardening Res. Dept., Hort. Res. Inst., ARC, Giza, Egypt. \\ ** Department of Horticulture, Faculty of Agriculture, Ain Shams University, Cairo, Egypt.
}

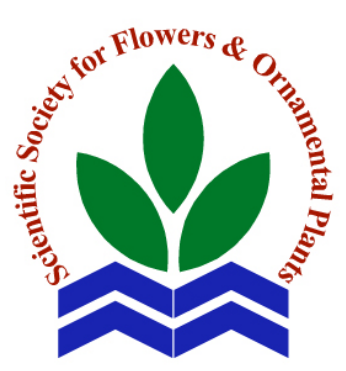

Scientific J. Flowers \& Ornamental Plants, 5(4):323-346 (2018).

Received: 3/12/2018 Accepted: 30/12/2018

ABSTRACT: This study was carried out in the nursery of Ornamental Plants and Landscape Gardening Research Department, Horticulture Research Institute, Agriculture Research Centre, Giza, Egypt in two successive seasons (2015/2016 and 2016/2017) to study the effect of soil drench with some bio- and chemical materials (moringa extract, potassium silicate, salicylic acid and ascorbic acid) combined with different water intervals (1, 2, 3 and 4 weeks) on vegetative growth, flowering and chemical composition of Euphorbia milii var. longifolia transplants grown in $25 \mathrm{~cm}$ plastic pots. Results could be briefed in the following: watering at 2 weeks seems to be more effective in increasing the values of most studied characters. On the other hand, both moringa extract and ascorbic acid resulted in the highest values of studied characters. Regarding combination between irrigation intervals and different bio- and chemical materials, all untreated control plants irrespective of their watering regime, in addition to plants watered at 4 weeks interval and treated with either moringa extract or potassium silicate, did not flower at all over the period of this study. Meantime, the same plants recorded the lowest values of many characters irrespective of the watering regime. Plants treated with moringa extract and watered at 1 week interval had the highest values of flower diameter, number of branches, root length and root fresh weight. Those watered at 2 weeks interval achieved the highest rank of number of leaves and flowers, flower diameter, fresh and dry weight of flowers, $\mathrm{P} \%, \mathrm{~K} \%$ and total chlorophyll content. Plants treated with ascorbic acid combined with irrigation at 2 weeks interval got the highest records of plant height, stem length, leaf length, fresh weight of leaves, stem fresh and dry weights, total chlorophyll and carotenoids content. In conclusion it is recommended to irrigate Euphorbia milii var. longifolia grown in $25 \mathrm{~cm}$ plastic pots at 2 weeks interval, combined with treating plants with either moringa extract or ascorbic acid in order to get the best results.

Key words: Euphorbia milii var. longifolia, irrigation intervals, moringa extract, potassium silicate, salicylic acid, ascorbic acid.

\section{INTRODUCTION}

Euphorbia milii Des Moul. (crown of thorns, Christ plant, Christ thorn) is a species of flowering plant in the spurge family Euphorbiaciae, native to Madagascar. It is a succulent climbing shrub growing to $1.8 \mathrm{~m}$ tall, with densely 


\section{Azza M. Abd-Elmoneim et al.}

spiny stems. It is much esteemed for its brilliant flower-like inflorescences. However, it is a slow-growing limitedbranching plant. These insufficiencies affect its use in different aspects of landscaping as bed, pot or hedge plant and even for indoor decoration (InterNet Site 1, 2017). In order to overcome this problem different irrigation regimes and some treatments were tried. These treatments include moringa extract, potassium silicate, salicylic acid and ascorbic acid.

As we face the threat of reduction in our quota the Nile River water, we are obliged to modulate irrigation methods to decrease water loss. Water is an important factor in the growth, development and productivity of plants. Hartmann et al. (2005) reported that water stress due to drought is the most significant abiotic factor limiting plant growth and development. Emmanuel (2014) stated that water is a major constituent of all living organisms which is involved in important biochemical processes including photosynthesis. Thus, its availability in adequate quantity and at biologically tolerable interval affects productivity of plant species.

Asres (1995), Anwar and Bhanger (2003), Bennett et al. (2003) and Emongor (2012) claimed that the moringa leaf contains proteins, minerals, vitamins, essential amino acids, glucosinolates, isothiocyanates and phenolics. Andrews (2006) and Price (2007) mentioned that the active growth enhancing substances in Moringa leaf extract are zeatin, dihydrozeatin and isopentyladenine which are natural (endogenous) cytokinins. Price (2007) stated that extracts from fresh Moringa leaves could be used as an effective plant growth enhancer. Fuglie (2000 a, b) reported that application of moringa extract increased maize growth. Both the same author and El-Awady (2003) stated that fresh Moringa oleifera leaves have been shown to have zeatin, a cytokinin related hormone. Moringa leaves sampled from various parts of the world were found to have high zeatin concentrations of $5-200 \mu \mathrm{g} / \mathrm{g}$ of leaves. Emongor (2015) observed that the use of Moringa leaf extract as a possible plant growth enhancer can provide a relatively environmentally safe, easily accessible and affordable means of increasing crop yields to meet the increasing demand of food.

Voogt and Sonneveld (2001) revealed that depending on the water source, irrigation water may contain trace amounts of Si. Datnoff et al. (2007) mentioned that Si may have beneficial effects to plants, alleviating biotic and abiotic stresses in crops like barley, cucumber, oat, rice, rye, sugarcane and wheat. Cavins et al. (2010) stated that silicon ( $\mathrm{Si}$ ) is a non-essential nutrient for most plants. However, in field crops it is known to affect plant growth and quality, photosynthesis, transpiration and enhance plant resistance to stresses such as drought. In floriculture production, most plants are grown in soilless substrates consisting primarily of peat moss or pine bark. In these substrates the silicon concentration is limited and its supplementation might be beneficial. Mattson and Leatherwood (2010) claimed that silicon ( $\mathrm{Si}$ ) has an active role in plant physiology. It is a beneficial nutrient that improves biotic and abiotic stress tolerance of several crop species. Vicente and Plasencia (2011) reported that salicylic acid (SA) is an endogenous signal mediating local and systemic plant defence responses against pathogens. SA plays a role during the plant response to abiotic stresses such as drought, chilling, heavy metal toxicity, heat, and osmotic stress. SA plays a crucial role in the regulation of physiological and biochemical processes during the entire lifespan of the plant.

Liu et al. (1997) ascertained that ascorbic acid affects nutritional cycle's activity in higher plants and plays an important role in the electron transport system. Noctor and Foyer (1998) and Smirnoff and Wheeler (2000) claimed that ascorbic acid influence mitosis and cell growth in plants. De Tullio et al. (1999) and 
Arrigoni and De Tullio (2000) stated that Lascorbic acid serves as a co-factor for many enzymes. Explained that ascorbic acid is important as a cofactor for a large number of key enzymes in plants. Smirnoff and Wheeler (2000); Arrigoni and De Tullio (2002); Pignocchi and Foyer (2003) and Gest et al. (2013) stated that ascorbic acid may contribute to maintaining photosynthesis, cell-cycle progression, cell wall expansion, gene expression, synthesis of many hormones, anthocyanin and flavonoids. ElKobisy et al. (2005) claimed that ascorbic acid affects plant growth and development, and plays a role in the electron transport system. Reda et al. 2005 and Abd El-Aziz et al. (2009) stated that vitamins, such as ascorbic acid, could be considered as bioregulator compounds which, in relatively low concentrations, exert profound influence on plant growth regulating factors that influence many physiological processes, such as synthesis of enzymes. They also act as co-enzymes and affects plant growth. Barth et al. (2006) reported that ascorbic acid serves as an important co-factor for the synthesis of some hormones, such as salicylic acid, ethylene and abscisic acid. Ascorbic acid affects phytohrmone-mediated signaling processes during the transition from the vegetative to the reproductive phase as well as the final stage of development and senescence.

\section{MATERIALS AND METHODS}

This study was carried out at the nursery of the Ornamental Plant Research Department, Horticulture Research Institute, Giza, Egypt in two seasons, 2015-2016 and 2016-2017. The second season was an exact repetition of the first one. On $1^{\text {st }}$ Sept. 2015 rooted cuttings of Euphorbia milii var. longifolia were used in this study were potted in $25 \mathrm{~cm}$ plastic pots filled with about $2 \mathrm{~kg}$ of a mixture of sand and peat moss at 1:1 (v:v).

A factorial experiment was laid out in a randomized block design in order to study the effect of two factors on growth and flowering of Euphorbia milii var. longifolia.
The first factor was some treatments comprising soil drench with a solution of one of the following: moringa extract, potassium silicate $\left(\mathrm{K}_{2} \mathrm{O}_{3} \mathrm{Si}\right)$, salicylic acid and ascorbic acid, the fifth treatment was plain water (as control treatment). In a scheduled times these additives were dissolved in the irrigation water, which was applied every 1 , 2,3 or 4 weeks, representing the second factor.

Amount of water used each time was equal to the field capacity, or more correctly, pot capacity, which was determined empirically as follows: three $25 \mathrm{~cm}$ pots filled with about $2 \mathrm{~kg}$ of the potting mixture were watered thoroughly to saturation and weighed. Pots were covered with aluminum foil to prevent evaporation before they were left in a cool shaded place to drain freely for 4 hours. They were weighed again to calculate weight of water held by the potting mixture. Mean of the three pots representing the field capacity was found to be $750 \mathrm{~g}$, equivalent to $750 \mathrm{~cm}^{3}$ of water/pot.

Thus, $750 \mathrm{~cm}^{3}$ of water were given to each pot in due time according to the irrigation schedule. Apart from the first time of irrigation, when all treatments were irrigated together, the second time when this congregational watering occurred was in the twelfth week. This means that at the end of 12 weeks, plants watered at $1,2,3$ and 4 weeks interval were given 9, 6, 3 and 2.25 liters of water, respectively.

However, this allocation was kept for spring (March, April and May) and autumn (September, October and November). In winter (December, January and February), one third of this amount $\left(250 \mathrm{~cm}^{3}\right)$ was deducted, to be given back in summer (June, July and August) to the same treatments in mid interval to make for the high summer temperature.

\section{Preparation of solutions:}

Moringa extract was made using a blender for homogenizing $25 \mathrm{~g}$ of young leaves with $100 \mathrm{ml}$ of water. Cheese cloth was used for filtration. The filtrate was used 
directly according to treatments. Water solution of potassium silicate was prepared at $500 \mathrm{mg} / \mathrm{l}$. Water solutions of both salicylic acid at $5 \mathrm{mg} / \mathrm{l}$ and ascorbic acid at $100 \mathrm{mg} / \mathrm{l}$ were prepared. When applied, $750 \mathrm{ml}$ of each substance was prepared and applied to each pot to serve as irrigation and treatment application simultaneously.

The experimental procedures started in September 2015. One year later, i.e. September 2016 data were recorded for: plant height $(\mathrm{cm})$, stem length $(\mathrm{cm})$, number of leaves, leaf length $(\mathrm{cm})$, leaf width $(\mathrm{cm})$, number of flowering clusters, number of flowers, flower diameter $(\mathrm{cm})$, number of branches, root length $(\mathrm{cm})$, stem fresh and dry weights (g), leaves fresh and dry weights (g), flowers fresh and dry weights (g) and roots fresh and dry weights (g).

Samples of leaves from the three replicates of each treatment were mixed together and determinations of total carbohydrate content (mg/g d.w.) were carried out according to Herbert et al. (1971); total chlorophyll and carotenoids (mg/g f.w.) according to Saric et al. (1976); percentages of nitrogen, phosphorus, and potassium according to Jackson (1973), in the Central Lab of the Horticulture Research Institute.

Data were statistically analyzed using analysis of variance as described by Snedecor and Cochran (1989) and means were compared by Duncan critical range at 5\% (Duncan, 1955) by means of SAS 1995 computer program.

\section{RESULTS}

1. Effect of irrigation intervals, treatments and their interaction on plant height, number of branches and stem characters (Table, 1):

\section{a. Plant height (cm):}

The effect of irrigation intervals on plant height was significant in both seasons. The tallest plants were those irrigated every 2 weeks, in addition to those watered every 1 week in the first season or every 3 weeks in the second one.

The shortest plants were those irrigated every 4 weeks, in addition to those supplied with water every 3 weeks in the first season or every 1 week in the second one.

The effect of treatments on plant height was significant in both seasons. The tallest plants were a result of treating plants with ascorbic acid. The second position was occupied by treatments of potassium silicate and salicylic acid; in addition to the moringa extract treatment in the second season only. The shortest plants were those treated with moringa extract in the first season, in addition to the untreated (control) plants, in the first and second seasons.

The effect of the interaction between irrigation intervals and treatments on plant height was significant in both seasons. The tallest plants were those treated with ascorbic acid and irrigated at either 2 or 3 weeks intervals, in addition to those treated with ascorbic acid and irrigated at either 1 or 4 weeks intervals; and those treated with moringa extract and irrigated at 4 weeks interval, in the second season. The shortest plants resulted when plants received no treatments (the control plants) and were watered at 4 weeks interval.

\section{b. Number of branches:}

The effect of irrigation intervals on number of branches was significant in both seasons. Watering plants at 1,2 or 3 weeks intervals gave rise to higher number of branches compared to watering at 4 weeks interval.

The effect of treatments on number of branches was significant in both seasons. Applying moringa extract, $\mathrm{K}_{2} \mathrm{O}_{3} \mathrm{Si}$, salicylic and ascorbic acids resulted in higher number of branches compared to the untreated control plants.

The effect of the interaction between irrigation intervals and treatments on number of branches was significant in both seasons. The highest number of branches belonged to 
Table 1. Effect of irrigation intervals, bio and chemical treatments and their interaction on plant height, number of branches and stem characters of Euphorbia milii var. longifolia.

\begin{tabular}{|c|c|c|c|c|c|c|c|c|c|c|}
\hline \multirow[t]{2}{*}{ Treat. } & \multicolumn{5}{|c|}{$\begin{array}{c}\text { First season } \\
\text { Irrigation intervals (weeks) }\end{array}$} & \multicolumn{5}{|c|}{$\begin{array}{c}\text { Second season } \\
\text { Irrigation intervals (weeks) }\end{array}$} \\
\hline & 1 & 2 & 3 & 4 & Mean & 1 & 2 & 3 & 4 & Mean \\
\hline & \multicolumn{10}{|c|}{ Plant height (cm) } \\
\hline Control & \multicolumn{4}{|c|}{30.67 f-h 32.03 d-g 26.83 hi 24.50 i } & \multicolumn{4}{|c|}{33.23 b-f 29.03 e-g 29.33 d-g 23.27 h } & $23.27 \mathrm{~h}$ & $28.72 \mathrm{C}$ \\
\hline Moringa & \multicolumn{4}{|c|}{26.93 hi 28.73 g-i 29.33 f-h 29.77 f-h } & \multirow{2}{*}{$\begin{array}{l}28.63 \mathrm{fg} \\
28.30 \mathrm{~g}\end{array}$} & \multicolumn{4}{|c|}{33.23 b-f 34.23 bc 35.50 a-c 35.50 a-c } & $32.90 \mathrm{~B}$ \\
\hline $\mathrm{K}_{2} \mathrm{O}_{3} \mathrm{Si}$ & \multicolumn{4}{|c|}{32.67 c-g 33.13 c-f 31.23 e-g 30.47 f-h } & & \multicolumn{4}{|c|}{34.50 bc 33.83 b-d 33.70 b-e 33.70 b-e } & $32.58 \mathrm{~B}$ \\
\hline Salicylic & \multicolumn{5}{|c|}{33.30 c-f 35.30 b-e 30.50 f-h 30.30 f-h 34.17 bc } & \multirow{2}{*}{$\begin{array}{c}33.80 \mathrm{~b}-\mathrm{d} \\
39.53 \mathrm{a}\end{array}$} & $30.90 \mathrm{c}-\mathrm{g}$ & $31.17 \mathrm{c}-\mathrm{g}$ & $31.17 \mathrm{c}-\mathrm{g}$ & $32.51 \mathrm{~B}$ \\
\hline Ascorbic & $36.03 \mathrm{a}-\mathrm{d}$ & 39.73 a & \multicolumn{2}{|c|}{37.73 ab $36.83 a-c$} & $34.60 \mathrm{bc}$ & & \multirow{2}{*}{\multicolumn{3}{|c|}{$\begin{array}{l}37.10 \text { ab } 33.17 \text { b-f } 33.17 \text { b-f } \\
34.02 A^{`} 33.08 \text { AB } 31.36 \text { B }\end{array}$}} & \multirow{2}{*}{$36.10 \mathrm{~A}$} \\
\hline \multirow[t]{2}{*}{ Mean } & 31.92 & $33.79 \mathrm{~A}^{\prime}$ & $31.13 \mathrm{~B}^{\backslash}$ & $30.37 \mathrm{~B}^{\backslash}$ & & $31.79 \mathrm{~B}$ & & & & \\
\hline & \multicolumn{10}{|c|}{ Number of branches } \\
\hline Control & $0.00 \mathrm{e}$ & $0.00 \mathrm{e}$ & $0.67 \mathrm{de}$ & 1.00 de & $0.42 \mathrm{~B}$ & $0.00 \mathrm{e}$ & 0.33 e & 0.33 e & $0.00 \mathrm{e}$ & $0.17 \mathrm{~B}$ \\
\hline Moringa & $6.00 \mathrm{a}$ & $4.33 \mathrm{a}-\mathrm{c}$ & $3.33 \mathrm{a}-\mathrm{d}$ & 1.33 c-e & $3.75 \mathrm{~A}$ & $6.67 \mathrm{a}$ & $4.00 \mathrm{a}-\mathrm{c}$ & 3.00 b-e & $0.67 \mathrm{de}$ & $3.58 \mathrm{~A}$ \\
\hline $\mathrm{K}_{2} \mathrm{O}_{3} \mathrm{Si}$ & 2.33 b-e & 2.67 b-e & $5.00 \mathrm{ab}$ & $0.00 \mathrm{e}$ & $2.50 \mathrm{~A}$ & 2.33 b-e & 3.00 b-e & 2.67 b-e & 1.00 c-e & $2.25 \mathrm{~A}$ \\
\hline Salicylic & 3.00 a-e & $4.33 \mathrm{a}-\mathrm{c}$ & 2.67 b-e & $0.00 \mathrm{e}$ & $2.50 \mathrm{~A}$ & $4.33 \mathrm{ab}$ & 3.00 b-e & 2.33 b-e & $0.00 \mathrm{e}$ & $2.42 \mathrm{~A}$ \\
\hline Ascorbic & 1.67 c-e & $5.33 \mathrm{ab}$ & $4.33 \mathrm{a}-\mathrm{c}$ & $0.67 \mathrm{de}$ & $3.00 \mathrm{~A}$ & 3.67 a-d & 2.67 b-e & 2.00 b-e & 0.00 e & $2.08 \mathrm{~A}$ \\
\hline \multirow[t]{2}{*}{ Mean } & $2.60 \mathrm{~A}^{\prime}$ & $3.33 \mathrm{~A}^{\prime}$ & $3.20 \mathrm{~A}^{\prime}$ & $0.60 \mathrm{~B}^{\backslash}$ & & $3.40 \mathrm{~A}^{\prime}$ & $2.60 \mathrm{~A}^{\prime}$ & $2.07 \mathrm{~A}^{\prime}$ & $0.33 \mathrm{~B}^{\prime}$ & \\
\hline & & & & & Stem len & ngth (cm) & & & & \\
\hline Control & 20.17 b-f & 18.77 b-f & 16.43 ef & $15.47 \mathrm{f}$ & 17.71 B & 18.53 c-f & 20.43 a-e & $16.87 \mathrm{~d}-\mathrm{f}$ & $14.27 \mathrm{f}$ & $17.52 \mathrm{C}$ \\
\hline Moringa & $18.13 \mathrm{c}-\mathrm{f}$ & 19.27 b-f & 27.88 a & 18.17 c-f & $20.86 \mathrm{AB}$ & 20.30 b-e & 22.67 a-c & $22.50 \mathrm{a}-\mathrm{c}$ & $18.67 \mathrm{c}-\mathrm{f}$ & $21.03 \mathrm{AB}$ \\
\hline $\mathrm{K}_{2} \mathrm{O}_{3} \mathrm{Si}$ & 19.68 b-f & $21.73 \mathrm{a}-\mathrm{f}$ & 21.00 b-f & 19.80 b-f & $20.55 \mathrm{AB}$ & $21.91 \mathrm{a}-\mathrm{d}$ & 22.90 a-c & $19.00 \mathrm{c}-\mathrm{f}$ & $16.13 \mathrm{ef}$ & 19.99 BC \\
\hline Salicylic & 22.30 a-e & 23.57 a-d & 20.83 b-f & $17.37 \mathrm{~d}-\mathrm{f}$ & $21.02 \mathrm{AB}$ & 20.83 a-e & 20.73 a-e & 20.50 a-e & $17.87 \mathrm{c}-\mathrm{f}$ & 19.98 BC \\
\hline Ascorbic & 21.40 a-f & $25.27 \mathrm{ab}$ & 24.23 a-c & 24.17 a-c & 23.77 A & $25.40 \mathrm{ab}$ & 25.63 a & 23.17 a-c & $18.41 \mathrm{c}-\mathrm{f}$ & $23.15 \mathrm{~A}$ \\
\hline Mean & $20.34 \mathrm{AB}^{\backslash}$ & $21.72 \mathrm{AB}^{\prime}$ & $22.08 \mathrm{~A}^{\prime}$ & $18.99 \mathrm{~B}^{\backslash}$ & & $21.40 \mathrm{~A}^{\prime}$ & $22.47 \mathrm{~A}^{\prime}$ & $20.41 \mathrm{~A}^{\prime}$ & 17.07 B & \\
\hline & & & & & & woight (o & & & & \\
\hline Control & $37.46 \mathrm{gh}$ & $38.53 \mathrm{f}-\mathrm{h}$ & $28.32 \mathrm{~h}$ & $27.81 \mathrm{~h}$ & $33.03 \mathrm{C}$ & 43.46 d-h & 34.14 g-i & 29.97 hi & $21.21 \mathrm{i}$ & $32.20 \mathrm{~B}$ \\
\hline Moringa & 44.33 d-g & $46.10 \mathrm{~d}-\mathrm{g}$ & 49.35 c-g & 42.59 e-h & $45.59 \mathrm{~B}$ & 38.84 e-i & 55.07 b-e & $61.93 \mathrm{a}-\mathrm{d}$ & 55.68 a-e & $52.88 \mathrm{~A}$ \\
\hline $\mathrm{K}_{2} \mathrm{O}_{3} \mathrm{Si}$ & 54.85 b-d & $54.45 \mathrm{~b}-\mathrm{d}$ & 48.94 c-g & 46.29 d-g & $51.13 \mathrm{~B}$ & 61.90 a-d & 66.78 a-c & 53.43 b-f & 33.22 g-i & $53.83 \mathrm{~A}$ \\
\hline Salicylic & 57.07 b-e & 58.69 b-d & 53.05 b-f & $37.53 \mathrm{gh}$ & 51.59 B & $61.23 \mathrm{a}-\mathrm{d}$ & 54.61 b-e & 50.77 c-g & $35.34 \mathrm{f}-\mathrm{i}$ & $50.49 \mathrm{~A}$ \\
\hline Ascorbic & 61.70 bc & 77.11 a & $66.04 \mathrm{ab}$ & 57.12 b-e & $65.49 \mathrm{~A}$ & $70.78 \mathrm{ab}$ & 74.50 a & $59.72 \mathrm{a}-\mathrm{d}$ & $33.42 \mathrm{~g}-\mathrm{i}$ & $59.61 \mathrm{~A}$ \\
\hline Mean & $51.08 \mathrm{~A}^{\prime}$ & $54.98 \mathrm{~A}^{\prime}$ & $49.14 \mathrm{~A}^{\prime}$ & $42.27 \mathrm{~B}^{\backslash}$ & & $55.24 \mathrm{~A}^{\prime}$ & $57.02 \mathrm{~A}^{\prime}$ & $51.16 \mathrm{~A}^{\prime}$ & $35.77 \mathrm{~B}^{\backslash}$ & \\
\hline & & & & & Stem & weight (g) & & & & \\
\hline Control & $2.24 \mathrm{fg}$ & 2.39 e-g & $1.77 \mathrm{~g}$ & $1.73 \mathrm{~g}$ & $2.03 \mathrm{C}$ & $1.98 \mathrm{gh}$ & $2.09 \mathrm{f}-\mathrm{h}$ & $1.87 \mathrm{gh}$ & $1.75 \mathrm{~h}$ & $1.92 \mathrm{~B}$ \\
\hline Moringa & 3.20 c-g & 3.61 b-g & 4.24 a-e & $2.58 \mathrm{e}-\mathrm{g}$ & 3.41 B & 3.76 a-e & 4.07 a-e & 4.12 a-e & $3.41 \mathrm{c}-\mathrm{g}$ & $3.84 \mathrm{~A}$ \\
\hline $\mathrm{K}_{2} \mathrm{O}_{3} \mathrm{Si}$ & 3.99 a-f & $5.11 \mathrm{ab}$ & 3.54 b-g & $2.73 \mathrm{~d}-\mathrm{g}$ & $3.84 \mathrm{AB}$ & 4.09 a-e & $5.30 \mathrm{a}$ & $3.26 \mathrm{~d}-\mathrm{h}$ & $2.52 \mathrm{e}-\mathrm{h}$ & $3.79 \mathrm{~A}$ \\
\hline Salicylic & 4.67 a-c & $4.84 \mathrm{a}-\mathrm{c}$ & 3.46 b-g & 2.45 e-g & $3.86 \mathrm{AB}$ & 4.06 a-e & $4.15 \mathrm{a}-\mathrm{d}$ & 3.60 b-f & $2.00 \mathrm{gh}$ & $3.45 \mathrm{~A}$ \\
\hline Ascorbic & $5.35 \mathrm{ab}$ & $5.51 \mathrm{a}$ & $4.53 \mathrm{a}-\mathrm{d}$ & 3.61 b-g & $4.75 \mathrm{~A}$ & 4.96 a-c & $5.17 \mathrm{ab}$ & 3.95 a-e & $2.71 \mathrm{~d}-\mathrm{h}$ & $4.20 \mathrm{~A}$ \\
\hline Mean & $3.89 \mathrm{~A}^{\prime}$ & $4.29 \mathrm{~A}^{\prime}$ & $3.51 \mathrm{~A}^{\backslash}$ & $2.62 \mathrm{~B}^{\backslash}$ & & $3.77 \mathrm{AB}^{\backslash}$ & $4.16 \mathrm{~A}^{\backslash}$ & $3.36 \mathrm{~B}^{\backslash}$ & $2.48 \mathrm{C}^{\backslash}$ & \\
\hline
\end{tabular}

Means with the same letter are not significantly different at $5 \%$ level according to Duncan. 
plants watered at 1 week interval and treated with moringa extract. The lowest record in the same question (here no branches were produced at all) was observed on untreated control plants watered at 1,2 weeks interval in the first season or at 1 or 4 weeks interval in the second one; in addition to plants watered at 4 weeks interval and treated with $\mathrm{K}_{2} \mathrm{O}_{3} \mathrm{Si}$ or salicylic acid in the first season; or with salicylic or ascorbic acids in the second one.

\section{c. Stem length $(\mathrm{cm})$ :}

The effect of irrigation intervals on stem length was significant in both seasons. Watering plants at 1, 2 or 3 weeks intervals gave rise to taller stems compared to 4 weeks interval.

The effect of treatments on plant height was significant in both seasons. The tallest stems were a result of applying ascorbic acid or moringa extract, in addition to $\mathrm{K}_{2} \mathrm{O}_{3} \mathrm{Si}$ or salicylic acid. The shortest stems were the untreated control plants in the first and second seasons.

3.2.c. Effect of the interaction between irrigation intervals and treatments:

The effect of the interaction between irrigation intervals and treatments on plant height was significant in both seasons. The tallest plants were those watered at 2 weeks interval and treated with ascorbic acid, in addition to those watered at 3 weeks and treated with moringa extract in the first season; or irrigated at 1 week interval and treated with ascorbic acid in the second one.

\section{d. Stem fresh weight (g):}

The effect of irrigation intervals on stem fresh weight was significant in both seasons. Plants watered at 1, 2 and 3 weeks interval got higher stem fresh weight than those watered at 4 weeks interval.

The effect of treatments on stem fresh weight was significant in both seasons. The heaviest fresh roots were produced by plants treated with ascorbic acid, in addition to those treated with moringa extract, $\mathrm{K}_{2} \mathrm{O}_{3} \mathrm{Si}$ and salicylic acid in the second season. The lightest fresh roots resulted when plants were left with no treatments at all, i.e. the control plants.

The effect of the interaction between irrigation intervals and treatments on stem fresh weight was significant in both seasons. The highest values in this respect were a result of treating plants with ascorbic acid and watering them at 2 or 3 weeks interval, or at 1 or 2 weeks interval. The lowest records were induced by the untreated control plants watered at 4 weeks interval.

\section{e. Stem dry weight (g):}

The effect of irrigation intervals on stem dry weight was significant in both seasons. The heaviest dry stems belonged to plants watered at 1, 2 or 3 weeks interval in the first season; and at 1 or 2 weeks interval in the second one. Irrigating plants at 4 weeks interval resulted in the lightest dry stems.

The effect of treatments on stem dry weight was significant in both seasons. Applying $\mathrm{K}_{2} \mathrm{O}_{3} \mathrm{Si}$, salicylic acid and ascorbic acid gave rise to the highest records in this question, besides using moringa extract in the second season. The lightest dry stems were produced by the untreated control plants.

The effect of the interaction between irrigation intervals and treatments on stem dry weight was significant in both seasons. The heaviest dry stems were produced when plants were watered at 2 weeks intervals and treated with $\mathrm{K}_{2} \mathrm{O}_{3} \mathrm{Si}$; in addition to plants treated with ascorbic acid and watered at 1 or 2 weeks interval in the first season or at 2 weeks intervals in the second one. The lowest records in the same regard belonged to the untreated control plants watered at 3 or 4 weeks in the first season or at 4 weeks interval in the second season.

\section{Effect of irrigation intervals, treatments and their interaction on leaves characters (Table, 2):}

\section{a. Number of leaves:}

The effect of irrigation intervals on number of leaves was significant in both 
Table 2. Effect of irrigation intervals, bio and chemical treatments and their interaction on leaves characters of Euphorbia milii var. longifolia.

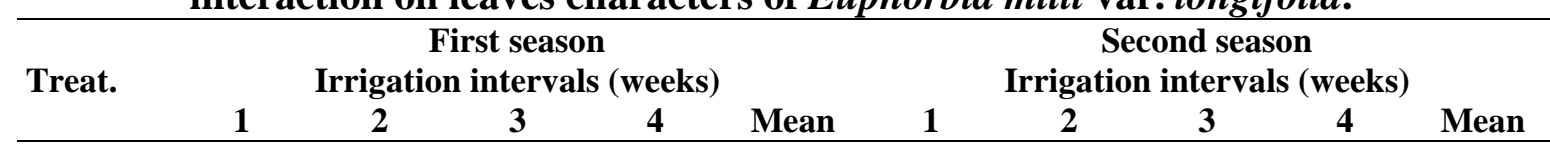

Number of leaves

Control 16.33 e 21.00 c-e 19.00 de 19.00 de 18.83 C 20.00 e-g 24.67 b-g 17.00 g 17.67 fg 19.83 B

Moringa 32.67 ab 34.67 ab 26.33 a-e 23.33 b-e 29.25 AB 35.33 a-c 40.67 a 32.67 a-e 23.00 c-g 32.92 A

$\mathrm{K}_{2} \mathbf{O}_{3} \mathrm{Si} \quad 29.00$ a-d 33.33 ab 24.00 b-e 19.00 de 26.33 AB 30.67 a-f 34.00 a-d 26.00 b-g 22.00 d-g $28.17 \mathrm{~A}$

Salicylic 31.67 a-c 24.33 b-e 24.67 b-e 19.00 de 24.92 B 35.67 a-c 26.67 b-g 25.67 b-g 18.67 fg 26.67 A

Ascorbic 31.00 a-c 33.33 ab 37.00 a 23.67 b-e 31.25 A 37.33 ab 30.33 a-f 27.33 b-g 21.00 d-g $29.00 \mathrm{~A}$

$\begin{array}{lllllllll}\text { Mean } & 28.13 \mathrm{~A}^{\prime} 29.33 \mathrm{~A}^{\prime} & 26.20 \mathrm{~A}^{\prime} & 20.80 & \mathrm{~B}^{\prime} & 31.80 \mathrm{~A}^{\prime} & 31.27 & 25.73 & 20.47 \mathrm{C}^{\prime}\end{array}$

\section{Leaf length $(\mathrm{cm})$}

Control $17.23 \mathrm{~b}-\mathrm{d} 17.67 \mathrm{~b}-\mathrm{d} \quad 15.10 \mathrm{~d} \quad 15.03 \mathrm{~d} \quad 16.26 \mathrm{C} \quad 17.83 \mathrm{c}-\mathrm{e} \quad 16.57 \mathrm{ef} \quad 16.67 \mathrm{ef} \quad 13.93 \mathrm{~g} \quad 16.25 \mathrm{C}$

Moringa $15.33 \mathrm{~cd} 16.80 \mathrm{~b}-\mathrm{d} 17.50 \mathrm{~b}-\mathrm{d} 17.53 \mathrm{~b}-\mathrm{d} 16.79 \mathrm{BC} 18.30 \mathrm{~cd} 18.23 \mathrm{~cd} 18.70 \mathrm{~b}-\mathrm{d} 16.07 \mathrm{f} \quad 17.83 \mathrm{~B}$

$\mathbf{K}_{2} \mathbf{O}_{3} \mathrm{Si} \quad 18.07$ b-d 18.33 b-d 17.80 b-d 17.83 b-d 18.01 BC 18.97 bc 18.80 b-d 17.50 c-f $15.97 \mathrm{f} \quad 17.81 \mathrm{~B}$

Salicylic $\quad 19.00$ b 17.80 b-d 18.47 b-d 18.70 bc 18.49 AB 18.67 b-d 18.63 b-d 17.97 c-e 16.57 ef 17.96 B

Ascorbic $\quad 19.23$ b 23.00 a $\quad 19.40$ b $\quad 19.40$ b 20.26 A 18.07 c-e 20.67 a 20.00 ab 17.40 d-f 19.03 A

Mean $\quad 17.77 \mathrm{~A}^{\prime} 18.72 \mathrm{~A}^{\prime} 17.65 \mathrm{~A}^{\prime} 17.70 \mathrm{~A}^{\prime} \quad 18.37 \mathrm{~A}^{\prime} 18.58 \mathrm{~A}^{\prime} 18.17 \mathrm{~A}^{\prime} 15.99 \mathrm{~B}^{\prime}$

\section{Leaf width (cm)}

Control $\quad 4.90$ e-g $5.13 \mathrm{~d}-\mathrm{g} \quad 4.57 \mathrm{fg} \quad 4.43 \mathrm{~g} \quad 4.76 \mathrm{~B} \quad 5.17 \mathrm{c}-\mathrm{f} \quad 4.80 \mathrm{e}-\mathrm{g} \quad 4.60 \mathrm{fg} \quad 4.17 \mathrm{~g} \quad 4.68 \mathrm{C}$

Moringa 5.43 c-f 5.50 c-f 5.63 b-e 5.83 a-e 5.60 A 5.77 a-d 5.83 a-d 5.90 ac 5.60 b-d 5.78 AB

$\mathrm{K}_{2} \mathrm{O}_{3} \mathrm{Si} \quad 6.17 \mathrm{a}$-c $\quad 6.73$ a $\quad 5.87$ a-e $5.17 \mathrm{~d}$-g $\quad 5.98 \mathrm{~A} \quad 6.07 \mathrm{ab} \quad 5.70 \mathrm{a}-\mathrm{d} \quad 5.57 \mathrm{bd} \quad 5.13 \mathrm{df} \quad 5.62 \mathrm{AB}$

Salicylic $5.97 \mathrm{a}-\mathrm{d} \quad 6.53 \mathrm{ab} \quad 5.67 \mathrm{~b}$-e $5.53 \mathrm{c}$-e $\quad 5.93 \mathrm{~A} \quad 5.60 \mathrm{~b}$-d $5.87 \mathrm{a}$-d $5.40 \mathrm{~b}$-e $5.30 \mathrm{c}$-f $5.54 \mathrm{~B}$

Ascorbic $\quad 6.10$ a-d 6.40 a-c 5.80 a-e 5.67 b-e 5.99 A $\quad 6.13$ ab $\quad 6.40$ a $\quad 5.83$ a-d 5.40 b-e $5.94 \mathrm{~A}$

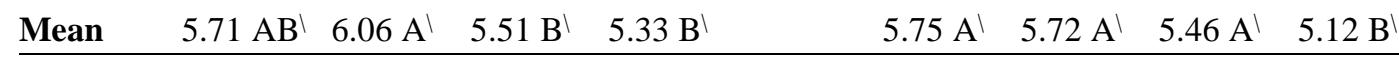

\section{Leaves fresh weight (g)}

Control $\quad 30.72$ e-g 36.48 c-g 23.86 g 23.09 g 28.54 D 40.09 b-f 31.42 e-h 24.29 gh 18.11 h 28.48 D

Moringa 26.32 fg 30.69 e-g 34.33 d-g 39.58 b-f 32.73 CD 44.28 b-e 49.29 a-c 48.74 a-c 36.33 c-g 44.66 AB

$\mathrm{K}_{2} \mathbf{O}_{3} \mathrm{Si} \quad 40.76$ b-f 40.08 b-f 38.08 b-g 36.25c-g 38.79 BC 41.74 b-e 45.24 b-d 42.30 b-e 19.11 h $\quad 37.10$ C

Salicylic 50.63 a-c 45.46 a-e 33.95 d-g 32.82 e-g 40.72 B 46.82 a-c 44.90 b-d 33.42 d-g 28.05 f-h 38.30 BC

Ascorbic 45.04 a-e 56.79 a 53.02 ab 47.98 a-d 50.71 A 52.62 ab 58.65 a 46.72 a-d 41.31 b-f 49.82 A

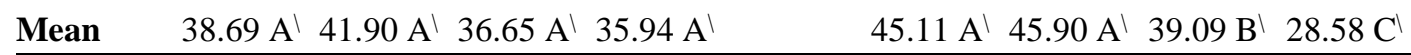

\begin{tabular}{|c|c|c|c|c|c|c|c|c|c|c|}
\hline \multirow[b]{2}{*}{ Control } & \multicolumn{10}{|c|}{ Leaves dry weight (g) } \\
\hline & $3.11 \mathrm{fg}$ & 3.78 e-g & $2.79 \mathrm{~g}$ & $2.83 \mathrm{~g}$ & $3.13 \mathrm{D}$ & $3.02 \mathrm{ef}$ & $3.33 \mathrm{~d}-\mathrm{f}$ & $3.24 \mathrm{~d}-\mathrm{f}$ & $2.54 \mathrm{f}$ & $3.03 \mathrm{D}$ \\
\hline Moringa & $4.13 \mathrm{~d}-\mathrm{g}$ & $4.30 \mathrm{~b}-\mathrm{g}$ & $4.24 \mathrm{c}-\mathrm{g}$ & $3.96 \mathrm{~d}-\mathrm{g}$ & $4.16 \mathrm{C}$ & $4.99 \mathrm{ab}$ & $5.07 \mathrm{ab}$ & $4.82 \mathrm{a}-\mathrm{c}$ & 4.12 b-e & $4.75 \mathrm{AB}$ \\
\hline $\mathrm{K}_{2} \mathrm{O}_{3} \mathrm{Si}$ & $4.77 \mathrm{~b}-\mathrm{g}$ & $4.60 \mathrm{~b}-\mathrm{g}$ & $3.92 \mathrm{~d}-\mathrm{g}$ & 3.69 e-g & $4.25 \mathrm{BC}$ & $4.99 \mathrm{ab}$ & $4.57 \mathrm{a}-\mathrm{d}$ & $3.39 \mathrm{c}-\mathrm{f}$ & 3.08 ef & $4.01 \mathrm{C}$ \\
\hline Salicylic & 6.16 a-c & 6.97 a & 3.86 e-g & $3.93 \mathrm{~d}-\mathrm{g}$ & $5.23 \mathrm{AB}$ & $5.16 \mathrm{ab}$ & $5.04 \mathrm{ab}$ & $3.46 \mathrm{c}-\mathrm{f}$ & $3.19 \mathrm{~d}-\mathrm{f}$ & $4.21 \mathrm{BC}$ \\
\hline Ascorbic & 5.18 a-e & $6.28 \mathrm{ab}$ & $5.87 \mathrm{a}-\mathrm{d}$ & $4.83 \mathrm{~b}-\mathrm{f}$ & $5.54 \mathrm{~A}$ & $5.53 \mathrm{ab}$ & $5.68 \mathrm{a}$ & $5.03 \mathrm{ab}$ & 4.49 a-e & $5.18 \mathrm{~A}$ \\
\hline Mean & $4.67 \mathrm{AB}^{\prime}$ & $5.19 \mathrm{~A}^{\prime}$ & $4.14 \mathrm{~B}^{\backslash}$ & $3.85 \mathrm{~B}^{\backslash}$ & & $4.74 \mathrm{~A}^{\prime}$ & $4.74 \mathrm{~A}^{\prime}$ & $3.99 \mathrm{~B}^{\prime}$ & $3.48 \mathrm{~B}^{\backslash}$ & \\
\hline
\end{tabular}

Means with the same letter are not significantly different at $5 \%$ level according to Duncan. 


\section{Azza M. Abd-Elmoneim et al.}

seasons. Irrigating plants at 1, 2 or 3 weeks intervals gave rise to greater number of leaves compared to the 4 weeks one in the first season. In the second one, the highest records in this concern were induced by watering at 1 or 2 weeks intervals, while the lowest number of leaves belonged to plants watered at 4 weeks interval.

The effect of treatments on plant height was significant in both seasons. The highest number of leaves was obtained when moringa extract, $\mathrm{K}_{2} \mathrm{O}_{3} \mathrm{Si}$ or ascorbic acid were applied, in addition to applying salicylic acid in the second season only. The lowest value in the same regard belonged to the untreated control plants.

The effect of the interaction between irrigation intervals and treatments was significant in both seasons. The highest number of leaves was noticed on plants irrigated at 2 weeks interval and treated with moringa extract, plants treated with ascorbic acid and irrigated at 2 or 3 weeks interval in the first season or at 1 week interval in the second one, in addition to plants irrigated at 1 or 2 weeks interval and treated with moringa extract or $\mathrm{K}_{2} \mathrm{O}_{3} \mathrm{Si}$ in the first season only. The lowest number of leaves was observed on the untreated control plants watered at either 1 or 3 weeks intervals in the first and second seasons.

\section{b. Leaf length (cm), Table (2):}

The effect of irrigation intervals on leaf length was significant in the second season only. However, the longest leaves were produced by plants irrigated at 2 weeks interval, in addition to those watered at 1 or 3 weeks interval in the second season only. The shortest leaves were a result of watering at 3 or 4 weeks interval.

The effect of treatments on leaf length was significant in both seasons. The longest leaves were noticed on plants treated with ascorbic acid, in addition to those treated with salicylic acid in the first season only. The shortest leaves belonged to the untreated control plants.
The effect of the interaction between irrigation intervals and treatments on leaf length was significant in both seasons. Irrigating plants at 2 weeks interval and treating them with ascorbic acid gave rise to the longest leaves, in addition to those watered at 3 weeks interval and treated with ascorbic acid in the second season only. The untreated control plants watered at 4 weeks interval had the shortest leaves, in addition to those watered at 3 weeks interval under the same treatment in the first season only.

\section{c. Leaf width (cm), Table (2):}

The effect of irrigation intervals on leaf width was significant in both seasons. Watering plants at 1 or 2 weeks interval induced the widest leaves in addition to irrigating at 3 weeks interval in the second only. The narrowest leaves were a result of irrigating at 4 weeks interval in addition to watering at 3 weeks interval in the first season only.

The effect of treatments on leaf width was significant in both seasons. The widest leaves belonged to plants treated with moringa extract, $\mathrm{K}_{2} \mathrm{O}_{3} \mathrm{Si}$ and ascorbic acid in addition to plants treated with salicylic acid in the first season only. The narrowest leaves were those of the untreated control plants.

The effect of the interaction between irrigation intervals and treatments on leaf length was significant in both seasons. The highest values in this concern were a result of irrigating at 2 weeks intervals and treating with either $\mathrm{K}_{2} \mathrm{O}_{3} \mathrm{Si}$ or salicylic acid in the first season; or treated with ascorbic acid and irrigated at 1 or 2 weeks intervals in the second one. The lowest records were a result of irrigating the untreated control plants at 4 weeks interval.

\section{d. Leaves fresh weight (g), Table (2):}

The effect of irrigation intervals on fresh weight of leaves was significant in the second season only. However, the heaviest fresh leaves were a result of watering plants at 2 weeks interval, in addition to those irrigated at 1 week interval in the second season. The lightest fresh leaves resulted 
when plants were irrigated at 4 weeks interval.

The effect of treatments on fresh weight of leaves was significant in both seasons. The highest values of this characteristic were induced when ascorbic acid was applied, in addition to using moringa extract in the second season. Untreated control plants had the lightest fresh weight of leaves.

The effect of the interaction between irrigation intervals and treatments on fresh weight of leaves was significant in both seasons. The heaviest fresh leaves were a function of combining between irrigation at 2 weeks interval and the ascorbic acid treatment, in addition to applying the aforementioned treatment and watering at 3 or 1 weeks interval in the first and second seasons. The lightest fresh leaves were noticed when the untreated control plants were irrigated at 4 weeks interval, in addition to watering the untreated control plants at 3 weeks interval in the first season or watering the $\mathrm{K}_{2} \mathrm{O}_{3}$ Si-treated plants at 4 weeks interval in the second season.

\section{e. Leaves dry weight (g):}

The effect of irrigation intervals on stem dry weight was significant in both seasons. Watering plants at 1 or 2 weeks interval gave rise to heavier dry leaves compared to watering at 3 or 4 weeks interval.

The effect of treatments on stem dry weight was significant in both seasons. Using salicylic acid or ascorbic acid in the first season; and moringa extract or ascorbic acid in the second season resulted in higher values of dry weight of leaves compared to results obtained from the untreated control plants.

The effect of the interaction between irrigation intervals and treatments on stem dry weight was significant in both seasons. The heaviest dry leaves belonged to plants watered at 2 weeks interval and treated with either salicylic acid in the first season or with ascorbic acid in the second season. The lowest results were obtained from the untreated control plants watered at 3 or 4 weeks interval in the first season or at 4 weeks interval in the second one.

\section{Effect of irrigation intervals, treatments and their interaction on flower characters (Table, 3):}

\section{a. Number of flower clusters:}

The effect of irrigation intervals on number of flower clusters was significant in both seasons. The largest number in this question was a result of watering pants at 2 or 3 weeks intervals, in addition to plants watered at 1 week interval in the first season only.

The effect of treatments on number of flower clusters was significant in both seasons. The highest number of flower clusters was induced when moringa extract or $\mathrm{K}_{2} \mathrm{O}_{3} \mathrm{Si}$ were applied, in addition to plants treated with salicylic acid in the second season only. The lowest values in this regard resulted when ascorbic acid was used. The untreated control plants failed to flower at all.

The effect of the interaction between irrigation intervals and treatments on number of flower clusters was significant in both seasons. In the first season, plants watered at 1 week interval and treated with moringa extract and those watered at 3 weeks interval and treated with $\mathrm{K}_{2} \mathrm{O}_{3} \mathrm{Si}$ gave rise to the highest number of flower clusters in the two season. In the second one, plants watered at 2 weeks interval and treated with moringa extract or those watered at 3 weeks interval and treated with salicylic acid induced the highest records. The lowest number of flower clusters resulted when ascorbic acid was applied to plants irrigated at 2, 3 or 4 weeks interval in the first season; or irrigated at 1 or 2 weeks interval in the second season, in addition to those treated with salicylic acid and irrigated at either 4 weeks interval in the first season or 1 week interval in the second one. All untreated control plants in both seasons, in addition to plants watered at 4 weeks interval and treated with moringa extract or $\mathrm{K}_{2} \mathrm{O}_{3} \mathrm{Si}$ in the first season; or with 
Table 3. Effect of irrigation intervals, bio and chemical treatments and their interaction on flower characters of Euphorbia milii var. longifolia.

\begin{tabular}{|c|c|c|c|c|c|c|c|c|c|c|}
\hline \multirow[t]{2}{*}{ Treat. } & \multicolumn{5}{|c|}{$\begin{array}{c}\text { First season } \\
\text { Irrigation intervals (weeks) }\end{array}$} & \multicolumn{5}{|c|}{$\begin{array}{c}\text { Second season } \\
\text { Irrigation intervals (weeks) }\end{array}$} \\
\hline & 1 & 2 & 3 & 4 & Mean & 1 & 2 & 3 & 4 & Mean \\
\hline & \multicolumn{10}{|c|}{ Number of flowering clusters } \\
\hline Control & $0.00 \mathrm{~g}$ & $0.00 \mathrm{~g}$ & $0.00 \mathrm{~g}$ & $0.00 \mathrm{~g}$ & $0.00 \mathrm{C}$ & $0.00 \mathrm{f}$ & $0.00 \mathrm{f}$ & $0.00 \mathrm{f}$ & $0.00 \mathrm{f}$ & $0.00 \mathrm{C}$ \\
\hline Moringa & $2.33 \mathrm{c}-\mathrm{f}$ & $4.00 \mathrm{~b}-\mathrm{d}$ & $5.00 \mathrm{ab}$ & $0.00 \mathrm{~g}$ & $2.83 \mathrm{~A}$ & $3.00 \mathrm{~b}-\mathrm{f}$ & $7.00 \mathrm{a}$ & $2.33 \mathrm{~b}-\mathrm{f}$ & $0.67 \mathrm{ef}$ & $3.25 \mathrm{~A}$ \\
\hline $\mathrm{K}_{2} \mathrm{O}_{3} \mathrm{Si}$ & $6.33 \mathrm{a}$ & $4.33 \mathrm{a}-\mathrm{c}$ & 3.33 b-e & $0.00 \mathrm{~g}$ & $3.50 \mathrm{~A}$ & 3.33 b-e & $4.33 \mathrm{a}-\mathrm{d}$ & $4.67 \mathrm{a}-\mathrm{c}$ & $1.67 \mathrm{c}-\mathrm{f}$ & $3.50 \mathrm{~A}$ \\
\hline Salicylic & $1.67 \mathrm{e}-\mathrm{g}$ & 3.00 b-e & $1.67 \mathrm{e}-\mathrm{g}$ & $0.33 \mathrm{fg}$ & $1.67 \mathrm{~B}$ & $0.33 \mathrm{ef}$ & $2.33 \mathrm{~b}-\mathrm{f}$ & $5.33 \mathrm{ab}$ & $0.00 \mathrm{f}$ & $2.00 \mathrm{AB}$ \\
\hline Ascorbic & $2.00 \mathrm{~d}-\mathrm{g}$ & $0.67 \mathrm{fg}$ & $0.67 \mathrm{fg}$ & $0.33 \mathrm{fg}$ & $0.92 \mathrm{BC}$ & $0.33 \mathrm{ef}$ & $1.00 \mathrm{ef}$ & $1.33 \mathrm{~d}-\mathrm{f}$ & $0.00 \mathrm{f}$ & $0.67 \mathrm{BC}$ \\
\hline \multirow[t]{2}{*}{ Mean } & $2.47 \mathrm{~A}^{\prime}$ & $2.40 \mathrm{~A}^{\prime}$ & $2.13 \mathrm{~A}^{\prime}$ & $0.13 \mathrm{~B}^{\prime}$ & & $1.40 \mathrm{BC}^{\prime}$ & $2.93 \mathrm{~A}^{\prime}$ & $2.73 \mathrm{AB}^{\prime}$ & $0.47 C^{\prime}$ & \\
\hline & \multicolumn{10}{|c|}{ Number of flowers } \\
\hline Control & $0.00 \mathrm{e}$ & 0.00 e & $0.00 \mathrm{e}$ & $0.00 \mathrm{e}$ & $0.00 \mathrm{C}$ & $0.00 \mathrm{e}$ & $0.00 \mathrm{e}$ & $0.00 \mathrm{e}$ & $0.00 \mathrm{e}$ & $0.00 \mathrm{C}$ \\
\hline Ioringa & $12.00 \mathrm{ab}$ & 15.67 a & $12.33 \mathrm{ab}$ & $0.00 \mathrm{e}$ & $10.00 \mathrm{~A}$ & 7.33 b-e & 23.67 a & 7.00 b-e & 1.33 e & $9.83 \mathrm{~A}$ \\
\hline${ }_{2} \mathrm{O}_{3} \mathrm{Si}$ & $15.33 \mathrm{a}$ & 15.67 a & $7.67 \mathrm{bc}$ & $0.00 \mathrm{e}$ & $9.67 \mathrm{~A}$ & 4.67 de & $15.00 \mathrm{~b}$ & $10.33 \mathrm{~b}-\mathrm{d}$ & 3.00 de & $8.25 \mathrm{AB}$ \\
\hline Salicylic & $2.67 \mathrm{de}$ & $7.00 \mathrm{~cd}$ & 4.67 c-e & $0.67 \mathrm{e}$ & $3.75 \mathrm{~B}$ & 0.67 e & 6.67 c-e & $13.67 \mathrm{bc}$ & 0.00 e & $5.25 \mathrm{~B}$ \\
\hline Ascorbic & 4.00 се & 0.67 e & $1.00 \mathrm{e}$ & 0.67 e & $1.58 \mathrm{BC}$ & $0.67 \mathrm{e}$ & $3.00 \mathrm{e}$ & $1.00 \mathrm{e}$ & $0.00 \mathrm{e}$ & $1.17 \mathrm{C}$ \\
\hline \multirow[t]{2}{*}{ Mean } & $6.80 \mathrm{AB}^{\prime}$ & $7.80 \mathrm{~A}^{\prime}$ & $5.13 \mathrm{~B}^{\prime}$ & $0.27 C^{\prime}$ & & $2.67 \mathrm{~B}^{\backslash}$ & $9.67 \mathrm{~A}^{\prime}$ & $6.40 \mathrm{~A}^{\prime}$ & $0.87 \mathrm{~B}^{\backslash}$ & \\
\hline & \multicolumn{10}{|c|}{ Flower diameter $(\mathrm{cm})$} \\
\hline Control & $0.00 \mathrm{~d}$ & $0.00 \mathrm{~d}$ & $0.00 \mathrm{~d}$ & $0.00 \mathrm{~d}$ & $0.00 \mathrm{C}$ & $0.00 \mathrm{e}$ & $0.00 \mathrm{e}$ & $0.00 \mathrm{e}$ & $0.00 \mathrm{e}$ & $0.00 \mathrm{C}$ \\
\hline Moringa & $4.00 \mathrm{a}$ & $4.23 \mathrm{a}$ & 3.97 a & $0.00 \mathrm{~d}$ & $3.05 \mathrm{~A}$ & $4.30 \mathrm{a}$ & $4.27 \mathrm{a}$ & $4.33 \mathrm{a}$ & 1.27 de & $3.54 \mathrm{~A}$ \\
\hline${ }_{2} \mathrm{O}_{3} \mathrm{Si}$ & $4.17 \mathrm{a}$ & $4.07 \mathrm{a}$ & $3.00 \mathrm{a}-\mathrm{c}$ & $0.00 \mathrm{~d}$ & $2.81 \mathrm{~A}$ & $2.50 \mathrm{a}-\mathrm{d}$ & $3.87 \mathrm{ab}$ & 3.77 a-c & $1.00 \mathrm{de}$ & $2.78 \mathrm{~A}$ \\
\hline Salicylic & $2.87 \mathrm{a}-\mathrm{c}$ & $3.73 \mathrm{ab}$ & $2.20 \mathrm{a}-\mathrm{d}$ & $1.17 \mathrm{~cd}$ & $2.49 \mathrm{~A}$ & $1.13 \mathrm{de}$ & $2.23 \mathrm{~b}-\mathrm{d}$ & $3.53 \mathrm{a}-\mathrm{c}$ & $0.00 \mathrm{e}$ & $1.73 \mathrm{~B}$ \\
\hline Ascorbic & $1.23 \mathrm{~cd}$ & $1.50 \mathrm{~b}-\mathrm{d}$ & $1.07 \mathrm{~cd}$ & $1.03 \mathrm{~cd}$ & $1.21 \mathrm{~B}$ & $1.30 \mathrm{de}$ & $2.87 \mathrm{a}-\mathrm{d}$ & $1.90 \mathrm{~cd}$ & $0.00 \mathrm{e}$ & $1.52 \mathrm{~B}$ \\
\hline \multirow[t]{2}{*}{ Mean } & $2.45 \mathrm{~A}^{\prime}$ & $2.71 \mathrm{~A}^{\prime}$ & $2.05 \mathrm{~A}^{\prime}$ & $0.44 \mathrm{~B}^{\backslash}$ & & $1.85 \mathrm{~B}^{\backslash}$ & $2.65 \mathrm{AB}^{\backslash}$ & $2.71 \mathrm{~A}^{\prime}$ & $0.45 \mathrm{C}^{\prime}$ & \\
\hline & \multicolumn{10}{|c|}{ Flowers fresh weight $(g)$} \\
\hline Control & $0.00 \mathrm{e}$ & $0.00 \mathrm{e}$ & $0.00 \mathrm{e}$ & $0.00 \mathrm{e}$ & $0.00 \mathrm{C}$ & $0.00 \mathrm{e}$ & $0.00 \mathrm{e}$ & $0.00 \mathrm{e}$ & $0.00 \mathrm{e}$ & $0.00 \mathrm{D}$ \\
\hline Moringa & $6.39 \mathrm{bc}$ & 10.90 a & $8.90 \mathrm{ab}$ & $0.00 \mathrm{e}$ & $6.55 \mathrm{~A}$ & $6.57 \mathrm{~b}-\mathrm{e}$ & $17.98 \mathrm{a}$ & $8.80 \mathrm{~b}-\mathrm{d}$ & 6.62 b-e & $9.99 \mathrm{~A}$ \\
\hline $\mathrm{K}_{2} \mathrm{O}_{3} \mathrm{Si}$ & $8.39 \mathrm{ab}$ & 10.05 a & $4.80 \mathrm{~cd}$ & $0.00 \mathrm{e}$ & $5.81 \mathrm{~A}$ & 3.42 c-e & $10.86 \mathrm{~b}$ & 5.64 b-e & 1.78 de & $5.43 \mathrm{~B}$ \\
\hline Salicylic & 2.68 de & $6.05 \mathrm{bc}$ & 1.59 de & $0.35 \mathrm{e}$ & $2.67 \mathrm{~B}$ & $0.68 \mathrm{e}$ & 4.91 b-e & $9.00 \mathrm{bc}$ & $0.00 \mathrm{e}$ & $3.65 \mathrm{BC}$ \\
\hline Ascorbic & 3.32 c-e & 0.89 e & 0.89 e & 0.09 e & $1.30 \mathrm{BC}$ & $0.84 \mathrm{e}$ & $1.82 \mathrm{de}$ & 1.81 de & $0.00 \mathrm{e}$ & $1.12 \mathrm{CD}$ \\
\hline \multirow[t]{2}{*}{ Mean } & 4.16 $\mathrm{AB}^{\prime}$ & $5.58 \mathrm{~A}^{\prime}$ & $3.24 \mathrm{~B}^{\prime}$ & $0.09 C^{\prime}$ & & $2.30 \mathrm{BC}^{\prime}$ & $7.12 \mathrm{~A}^{\backslash}$ & $5.05 \mathrm{AB}^{\backslash}$ & $1.68 \mathrm{C}^{\prime}$ & \\
\hline & \multicolumn{10}{|c|}{ Flowers dry weight (g) } \\
\hline Control & $0.00 \mathrm{e}$ & $0.00 \mathrm{e}$ & $0.00 \mathrm{e}$ & $0.00 \mathrm{e}$ & $0.00 \mathrm{C}$ & $0.00 \mathrm{~g}$ & $0.00 \mathrm{~g}$ & $0.00 \mathrm{~g}$ & $0.00 \mathrm{~g}$ & $0.00 \mathrm{C}$ \\
\hline Moringa & 0.78 b-e & $1.84 \mathrm{a}$ & $1.00 \mathrm{~b}$ & $0.00 \mathrm{e}$ & $0.91 \mathrm{~A}$ & 0.70 de & $1.58 \mathrm{a}$ & $0.79 \mathrm{~b}-\mathrm{d}$ & $0.09 \mathrm{fg}$ & $0.79 \mathrm{~A}$ \\
\hline $\mathrm{K}_{2} \mathrm{O}_{3} \mathrm{Si}$ & $1.10 \mathrm{ab}$ & 0.91 bc & 0.64 b-e & $0.00 \mathrm{e}$ & $0.66 \mathrm{~A}$ & $0.43 \mathrm{~d}-\mathrm{g}$ & $1.22 \mathrm{ab}$ & $0.76 \mathrm{~cd}$ & 0.29 e-g & $0.68 \mathrm{~A}$ \\
\hline Salicylic & 0.34 b-e & $0.29 \mathrm{~b}-\mathrm{e}$ & 0.50 b-e & $0.86 \mathrm{~b}-\mathrm{d}$ & $0.50 \mathrm{AB}$ & $0.02 \mathrm{~g}$ & $0.52 \mathrm{~d}-\mathrm{f}$ & $1.18 \mathrm{a}-\mathrm{c}$ & $0.00 \mathrm{~g}$ & $0.43 \mathrm{~B}$ \\
\hline Ascorbic & 0.34 b-e & 0.12 c-e & $0.01 \mathrm{e}$ & 0.05 ed & $0.13 \mathrm{BC}$ & $0.15 \mathrm{fg}$ & $0.39 \mathrm{~d}-\mathrm{g}$ & $0.31 \mathrm{e}-\mathrm{g}$ & $0.00 \mathrm{~g}$ & $0.21 \mathrm{BC}$ \\
\hline Mean & $0.51 \mathrm{AB}^{\prime}$ & $0.63 \mathrm{~A}^{\prime}$ & $0.43 \mathrm{AB}^{\backslash}$ & $0.18 \mathrm{~B}^{\backslash}$ & & $0.26 \mathrm{~B}^{\prime}$ & $0.74 \mathrm{~A}^{\prime}$ & $0.61 \mathrm{~A}^{\prime}$ & $0.08 \mathrm{~B}^{\backslash}$ & \\
\hline
\end{tabular}

Means with the same letter are not significantly different at $5 \%$ level according to Duncan. 
salicylic acid or ascorbic acid in the second season, failed to flower at all.

\section{b. Number of flowers:}

The effect of irrigation intervals on number of flowers was significant in both seasons. The highest number in this regard belonged to plants watered at 2 weeks intervals in addition to plants irrigated at 1 week interval in the first season or at 3 weeks intervals in the second one. The lowest number of flowers was a result of watering at 4 weeks intervals in addition to plants irrigated at 1 week in the second season.

The effect of treatments on number of flowers was significant in both seasons. The highest values in this concern belonged to plants treated with moringa extract or $\mathrm{K}_{2} \mathrm{O}_{3} \mathrm{Si}$. The lowest number of flowers resulted when ascorbic acid was used. The untreated control plants failed to flower at all.

The effect of the interaction between irrigation intervals and treatments on number of flowers was significant in both seasons. The largest number of flowers was induced when plants irrigated at 2 weeks interval and were treated with moringa extract, in addition to plants watered at 1 week interval and treated with either moringa extract or $\mathrm{K}_{2} \mathrm{O}_{3} \mathrm{Si}$, watered at 2 weeks interval and treated with $\mathrm{K}_{2} \mathrm{O}_{3} \mathrm{Si}$, or watered at 3 weeks interval and treated with moringa extract in the first season only. The lowest number of flowers belonged to plants treated with ascorbic acid and watered at 2 or 3 weeks intervals, in addition to plants watered at 4 weeks intervals and treated with either salicylic acid or ascorbic acid in the first season or watered at 1 week interval and treated with either salicylic acid or ascorbic acid in the second one, besides those watered at 4 weeks intervals and treated with moringa extract in the second season.

All untreated control plants in both seasons, in addition to plants watered at 4 weeks interval and treated with moringa extract or $\mathrm{K}_{2} \mathrm{O}_{3} \mathrm{Si}$ in the first season; or with salicylic acid or ascorbic acid in the second season, failed to flower at all.

\section{c. Flower diameter (cm):}

The effect of irrigation intervals on flower diameter was significant in both seasons. The widest flowers resulted when plants were watered at 2 or 3 weeks intervals, in addition to plants irrigated at 1 week interval in the first season.

The effect of treatments on flower diameter was significant in both seasons. The highest records in this regard were induced when moringa or $\mathrm{K}_{2} \mathrm{O}_{3} \mathrm{Si}$ were applied, in addition to using salicylic acid in the first season. The lowest values of flower diameter resulted when ascorbic acid was used, in addition to using salicylic acid in the second season only. Untreated control plants did not flower at all.

The effect of the interaction between irrigation intervals and treatments on flower diameter was significant in both seasons. The widest flowers were a result of applying moringa extract and irrigating plants at 1,2 or 3 weeks intervals, in addition to using $\mathrm{K}_{2} \mathrm{O}_{3} \mathrm{Si}$ and irrigating plants at 1 or 2 weeks intervals in the first season; or at 2 weeks interval in the second season; besides using salicylic acid and irrigating plants at 2 weeks interval in the first season only. The lowest records of flower diameter were noticed in plants treated with salicylic or ascorbic acids and watered at either 4 weeks interval in the first season; or at 1 week interval in the second season; in addition to plants treated with ascorbic acids and watered at either 1 or 3 weeks interval in the first season; or watered at 4 weeks interval and treated with either moringa extract or $\mathrm{K}_{2} \mathrm{O}_{3} \mathrm{Si}$ in the second season.

All untreated control plants in both seasons, in addition to plants watered at 4 weeks interval and treated with moringa extract or $\mathrm{K}_{2} \mathrm{O}_{3} \mathrm{Si}$ in the first season; or with salicylic acid or ascorbic acid in the second season, failed to flower at all. 


\section{Azza M. Abd-Elmoneim et al.}

\section{d. Flowers fresh weight (g):}

The effect of irrigation intervals on fresh weight of flowers was significant in both seasons. Irrigating plants at 2 weeks interval induced the heaviest fresh flowers, in addition to plants watered at 1 or 3 weeks interval. The lightest fresh flowers resulted when plants were watered at 4 weeks interval.

The effect of treatments on fresh weight of leaves was significant in both seasons. Applying moringa extract gave rise to the heaviest fresh flowers, in addition to plants treated with $\mathrm{K}_{2} \mathrm{O}_{3} \mathrm{Si}$ in the first season. Using ascorbic acid resulted in the lightest fresh flowers. Untreated control plants did not flower at all.

The effect of the interaction between irrigation intervals and treatments on fresh weight of flowers was significant in both seasons. The highest records in this question were obtained when plants treated with moringa extract were watered at 2 or 3 weeks interval in the first season, or at 2 weeks interval in the second one; in addition to plants treated with $\mathrm{K}_{2} \mathrm{O}_{3} \mathrm{Si}$ were watered at 1 or 2 weeks interval in the first season.

The lowest values of fresh weight of flowers were noticed on plants treated with salicylic or ascorbic acids and watered at either 4 weeks interval

All untreated control plants in both seasons, in addition to plants watered at 4 weeks interval and treated with moringa extract or $\mathrm{K}_{2} \mathrm{O}_{3} \mathrm{Si}$ in the first season; or with salicylic acid or ascorbic acid in the second season, failed to flower at all.

\section{e. Flowers dry weight (g):}

The effect of irrigation intervals on dry weight of flowers was significant in both seasons. Higher values of this trait were obtained when plants were irrigated at 1,2 or 3 weeks interval in the first season and at 2 or 3 weeks interval in the second season; compared to plants watered at 4 weeks interval and those watered at 1 week interval in the second season.
The effect of treatments on dry weight of flowers was significant in both seasons. Using moringa extract and $\mathrm{K}_{2} \mathrm{O}_{3} \mathrm{Si}$ resulted in the highest records of this character; in addition to using salicylic acid in the first season. Ascorbic acid induced the lowest values in the same question. The untreated control plants did not flower at all.

The effect of the interaction between irrigation intervals and treatments on stem dry weight was significant in both seasons. The highest dry weight of flowers was a result of watering plants at 2 weeks interval and treating them with moringa extract; in addition to treating plants with $\mathrm{K}_{2} \mathrm{O}_{3} \mathrm{Si}$ and watering at either 1 week interval in the first season or at 2 weeks interval in the second one. The lowest values of this trait were induced when plants were watered at 3 weeks interval combined with ascorbic acid in the first season or at 1 week interval combined with salicylic acid in the second season.

All untreated control plants in both seasons, in addition to plants watered at 4 weeks interval and treated with moringa extract or $\mathrm{K}_{2} \mathrm{O}_{3} \mathrm{Si}$ in the first season; or with salicylic acid or ascorbic acid in the second season, failed to flower at all.

\section{Effect of irrigation intervals, treatments and their interaction on root characters (Table, 4):}

\section{a. Root length (cm):}

The effect of irrigation intervals on root length was significant in the first season only. Irrespective of this observation, it could be noticed that irrigating plants at 1,2 or 3 weeks interval gave rise to longer roots, compared to watering at 4 weeks.

The effect of treatments on root length was significant in both seasons. Using moringa extract, $\mathrm{K}_{2} \mathrm{O}_{3} \mathrm{Si}$, salicylic acid or ascorbic acid resulted in longer roots, compared to roots of the untreated control plants.

The effect of the interaction between irrigation intervals and treatments on root 
Table 4. Effect of irrigation intervals, bio and chemical treatments and their interaction on root characters of Euphorbia milii var. longifolia.

\begin{tabular}{|c|c|c|c|c|c|c|c|c|c|c|}
\hline \multirow[t]{2}{*}{ Treat. } & \multicolumn{5}{|c|}{$\begin{array}{c}\text { First season } \\
\text { Irrigation intervals (weeks) }\end{array}$} & \multicolumn{5}{|c|}{$\begin{array}{c}\text { Second season } \\
\text { Irrigation intervals (weeks) }\end{array}$} \\
\hline & 1 & 2 & 3 & 4 & Mean & 1 & 2 & 3 & 4 & Mean \\
\hline & \multicolumn{10}{|c|}{ Root length (cm) } \\
\hline ontrol & $33.60 \mathrm{~cd}$ & $40.30 \mathrm{~b}-\mathrm{d}$ & $38.70 \mathrm{~b}-\mathrm{d}$ & $29.27 \mathrm{~d}$ & 35.47 B & $28.03 \mathrm{~d}$ & $44.50 \mathrm{ab}$ & $40.23 \mathrm{a}-$ & & $35.68 \mathrm{~B}$ \\
\hline & $7.17 \mathrm{a}$ & $47.33 \mathrm{a}-\mathrm{c}$ & $43.00 \mathrm{a}-\mathrm{d}$ & 41.33 & $47.21 \mathrm{~A}$ & 50.17 a & $39.27 \mathrm{a}$ & $9.60 \mathrm{a}$ & & 11 \\
\hline $\mathrm{K}_{2} \mathrm{O}_{3} \mathrm{Si}$ & $47.63 \mathrm{a}-\mathrm{c}$ & $52.17 \mathrm{ab}$ & 4 & .01 & $46.99 \mathrm{~A}$ & $44.50 \mathrm{ab}$ & $43.50 \mathrm{a}$ & $2.83 a$ & 00 & $3 \mathrm{~A}$ \\
\hline Salicylic & $50.50 \mathrm{ab}$ & $45.07 \mathrm{a}-\mathrm{d}$ & 4 & 3 & 64 & $48.17 \mathrm{ab}$ & $41.50 \mathrm{a}-\mathrm{d}$ & $40.50 \mathrm{a}$ & $-d$ & $17 \mathrm{AB}$ \\
\hline Ascorbic & $41.17 \mathrm{a}-$ & $46.83 \mathrm{a}-\mathrm{c}$ & $47.40 \mathrm{a}-$ & 46.47 & & & & $45.77 \mathrm{ab}$ & & $442.77 \mathrm{~A}$ \\
\hline \multirow[t]{2}{*}{ Mean } & $46.01 \mathrm{~A}^{\backslash}$ & $46.34 \mathrm{~A}^{\backslash}$ & 43.99 & $37.88 \mathrm{~B}^{\backslash}$ & & $41.47 \mathrm{~A}^{\backslash}$ & $43.46 \mathrm{~A}^{\prime}$ & $41.79 \mathrm{~A}^{\backslash}$ & & \\
\hline & \multicolumn{10}{|c|}{ Roots fresh weight (g) } \\
\hline Con & $4.93 \mathrm{~g}$ & $6.19 \mathrm{fg}$ & $5.76 \mathrm{~g}$ & $5.43 \mathrm{~g}$ & $5.58 \mathrm{C}$ & $4.88 \mathrm{~d}$ & $4.57 \mathrm{~d}$ & $4.15 \mathrm{~d}$ & $2.58 \mathrm{~d}$ & $5 \mathrm{C}$ \\
\hline nga & $18.44 \mathrm{a}$ & $15.65 \mathrm{ab}$ & $13.37 \mathrm{a}-\mathrm{d}$ & $10.11 \mathrm{c}-\mathrm{g}$ & $14.39 \mathrm{~A}$ & $18.00 \mathrm{a}$ & $16.52 \mathrm{a}$ & $13.88 \mathrm{ab}$ & $13.22 \mathrm{ab}$ & $15.41 \mathrm{~A}$ \\
\hline $\mathrm{K}_{2} \mathrm{O}_{3} \mathrm{Si}$ & $11.55 \mathrm{~b}-\mathrm{f}$ & 13.59 a-d & & $5.91 \mathrm{~g}$ & $11.40 \mathrm{~B}$ & & $17.00 \mathrm{a}$ & 18.05 a & $13.67 \mathrm{ab}$ & $16.00 \mathrm{~A}$ \\
\hline licylic & 15.09 a-c & 12 & & 6.74 & $11.52 \mathrm{~B}$ & $15.09 \mathrm{a}$ & $13.60 \mathrm{ab}$ & $13.31 \mathrm{ab}$ & $6.26 \mathrm{~cd}$ & $12.07 \mathrm{~B}$ \\
\hline Ascorbic & 12.07 b-e & $15.26 \mathrm{a}-\mathrm{c}$ & $12.90 \mathrm{bd}$ & $8.74 \mathrm{~d}-\mathrm{g}$ & $12.24 \mathrm{AB}$ & $11.82 \mathrm{a}-\mathrm{c}$ & $13.77 \mathrm{ab}$ & $12.18 \mathrm{a}-\mathrm{c}$ & $8.78 \mathrm{~b}-\mathrm{d}$ & $11.64 \mathrm{~B}$ \\
\hline \multirow[t]{2}{*}{ Mean } & $12.42 \mathrm{~A}^{\backslash}$ & $12.60 \mathrm{~A}^{\prime}$ & $11.70 \mathrm{~A}^{\backslash}$ & 7.39 B & & $13.01 \mathrm{~A}^{\backslash}$ & $13.09 \mathrm{~A}^{\prime}$ & $12.31 \mathrm{~A}^{\backslash}$ & $8.90 \mathrm{~B}^{\backslash}$ & \\
\hline & \multicolumn{10}{|c|}{ Roots dry weight (g) } \\
\hline & $0.91 \mathrm{f}$ & $1.17 \mathrm{f}$ & $1.38 \mathrm{f}$ & $1.11 \mathrm{f}$ & & & $0.96 \mathrm{~h}$ & $0.82 \mathrm{~h}$ & $0.79 \mathrm{~h}$ & $4 \mathrm{C}$ \\
\hline Moringa & $3.29 \mathrm{~b}$ & 3.19 bc & $2.98 \mathrm{bc}$ & 2.44 b-e & $2.97 \mathrm{~A}$ & 3.34 a-c & $3.54 \mathrm{ab}$ & 3.93 a & $2.67 \mathrm{~b}-\mathrm{f}$ & $3.37 \mathrm{~A}$ \\
\hline $\mathrm{K}_{2} \mathrm{O}_{3} \mathrm{Si}$ & $2.50 \mathrm{~b}-\mathrm{d}$ & $3.02 \mathrm{bc}$ & 2.34 c-e & 1.52 ef & $2.35 \mathrm{~B}$ & 3.12 a-e & $3.25 \mathrm{a}-\mathrm{d}$ & $2.17 \mathrm{e}-\mathrm{g}$ & $1.42 \mathrm{gh}$ & $2.49 \mathrm{~B}$ \\
\hline Salicylic & & $2.53 \mathrm{~b}-\mathrm{d}$ & $2.46 \mathrm{~b}-\mathrm{d}$ & $1.34 \mathrm{f}$ & $2.67 \mathrm{AB}$ & 3.05 a-e & $3.25 \mathrm{a}-\mathrm{d}$ & $2.83 \mathrm{~b}-\mathrm{e}$ & $1.09 \mathrm{~h}$ & $2.56 \mathrm{~B}$ \\
\hline Ascorbic & 2.56 bc & 3.09 bc & 2.45 b-e & $1.61 \mathrm{~d}-\mathrm{f}$ & $2.43 \mathrm{~B}$ & 2.46 c-g & 2.70 b-e & $2.28 \mathrm{~d}-\mathrm{g}$ & $1.63 \mathrm{f}-\mathrm{h}$ & $2.27 \mathrm{~B}$ \\
\hline Mean & $2.72 \mathrm{~A}^{\backslash}$ & $2.60 \mathrm{~A}^{\prime}$ & $2.32 \mathrm{~A}^{\prime}$ & $1.60 \mathrm{~B}^{\backslash}$ & & $2.55 \mathrm{~A}^{\prime}$ & $2.74 \mathrm{~A}^{\backslash}$ & $2.41 \mathrm{~A}^{\prime}$ & $1.52 \mathrm{~B}^{\backslash}$ & \\
\hline
\end{tabular}

Means with the same letter are not significantly different at $5 \%$ level according to Duncan.

length was significant in both seasons. The highest values in this concern occurred when plants watered at 1 week interval were treated with either moringa extract or salicylic acid, in addition to those watered at 2 weeks interval and treated with $\mathrm{K}_{2} \mathrm{O}_{3} \mathrm{Si}$ in the first season; and when plants watered at 1 week interval were treated with moringa extract, $\mathrm{K}_{2} \mathrm{O}_{3} \mathrm{Si}$ or salicylic acid, in addition to those watered at 2 weeks interval and were lift untreated or treated with ascorbic acid, together with plants watered at 3 weeks interval and treated with ascorbic acid. The shortest roots were produced by the untreated control plants watered at either 4 or 1 week intervals.

\section{b. Roots fresh weight (g):}

The effect of irrigation intervals on root fresh weight was significant in both seasons. Plants watered at 1, 2 and 3 weeks interval got heavier root fresh weight than those watered at 4 weeks interval.

The effect of treatments on root fresh weight was significant in both seasons. Applying moringa extract resulted in the heaviest fresh roots, in addition to using ascorbic acid in the first season or $\mathrm{K}_{2} \mathrm{O}_{3} \mathrm{Si}$ in the second one. The lowest records in this concern belonged to the untreated control plants.

The effect of the interaction between irrigation intervals and treatments on root fresh weight was significant in both seasons. Treating plants with moringa extract and watering them at 1 week interval gave rise to the highest values of root fresh weight, in addition to plants having the same treatment but watered at 2 weeks interval in the second season. Plants in the second season treated with $\mathrm{K}_{2} \mathrm{O}_{3} \mathrm{Si}$ and watered at 1,2 or 3 weeks interval besides those treated with salicylic 
acid and irrigated at 1 week interval shared also in the first position in this regard. The lowest values of root fresh weight were obtained by the untreated control plants watered at 1,3 or 4 weeks interval in the first season, or at 1, 2, 3 or 4 weeks interval in the second one.

\section{c. Roots dry weight (g):}

The effect of irrigation intervals on root dry weight was significant in both seasons. Watering plants at 1,2 or 3 weeks interval resulted in heavier dry roots compared to watering at 4 weeks interval.

The effect of treatments on root dry weight was significant in both seasons. Using moringa extract resulted in the heaviest dry roots, in addition to using salicylic acid in the first season. The lightest root dry weight belonged to the untreated control plants.

The effect of the interaction between irrigation intervals and treatments on root dry weight was significant in both seasons. Applying salicylic acid on plants watered at 1 week interval gave rise to the highest value of root dry weight in the first season, while in the second one this superiority was attributed to using moringa extract on plants watered at 2 or 3 weeks interval. The lowest records in this concern were obtained by the untreated control plants whatever the watering regime was at $1,2,3$ or 4 weeks interval, in addition to plants watered at 4 weeks interval and treated with salicylic acid.

\section{Effect of irrigation intervals, treatments and their interaction on mineral contents (Table, 5):}

\section{a. $\mathbf{N}(\%)$ :}

Watering plants at 2 or 3 weeks interval induced the highest $\mathrm{N} \%$, while watering at 1 week interval resulted in the lowest percentage of $\mathrm{N}$.

Applying $\mathrm{K}_{2} \mathrm{O}_{3} \mathrm{Si}$ gave rise to the highest value of $\mathrm{N} \%$. On the other hand, the untreated control plants had the lowest record in the same question.
Plants watered at 2 weeks interval and treated with $\mathrm{K}_{2} \mathrm{O}_{3} \mathrm{Si}$ obtained the highest position concerning $\mathrm{N} \%$, while the untreated control plants watered at 1 week interval occupied the lowest rank of the same character.

b. $\mathbf{P}$ (\%):

The highest percentage of $\mathrm{P}$ was detected in plants watered at 2 weeks interval, while the lowest was obtained when plants were irrigated every 4 weeks.

Treating plants with $\mathrm{K}_{2} \mathrm{O}_{3} \mathrm{Si}$ induced the highest value of $\mathrm{P} \%$, while ascorbic acid was the cause of getting the lowest one.

Plants watered at 2 weeks interval and treated with moringa extract obtained the highest $\mathrm{P} \%$, while those treated with ascorbic aid and watered at either 1 or 4 weeks interval had the lowest record in the same regard.

\section{c. K (\%):}

The highest K\% was detected in plants watered at 2 weeks interval, while the lowest was obtained when plants were irrigated at 4 weeks.

Treating plants with moringa extract induced the highest value of $\mathrm{K} \%$, while ascorbic acid induced the lowest one.

Plants watered at 2 weeks interval and treated with moringa extract gave the highest $\mathrm{K} \%$, while those treated with salicylic acid and watered at 1 week interval had the lowest record in the same concern.

\section{Effect of irrigation intervals, treatments and their interaction on carbohydrates and pigment contents (Table, 6 ):}

\section{a. Total carbohydrate (\%):}

The highest total carbohydrates\% was detected in plants watered at 3 weeks interval, while the lowest one was observed when plants were irrigated at 1 week.

Plants treated with moringa extract had the highest value of total carbohydrate\%, while ascorbic acid induced the lowest one. 
Table 5. Effect of irrigation intervals, bio and chemical treatments and their interaction on mineral contents of Euphorbia milii var. Iongifolia.

\begin{tabular}{lccccc}
\hline Treat. & $\mathbf{1}$ & $\mathbf{2}$ & $\mathbf{3}$ & $\mathbf{4}$ & Mean \\
\hline Control & 0.66 & 1.65 & $\mathbf{N} \mathbf{( \% )}$ & & \\
Moringa & 1.32 & 2.43 & 1.76 & 1.76 & 1.46 \\
$\mathbf{K}_{2} \mathbf{O}_{3} \mathbf{S i}$ & 2.21 & 2.43 & 2.21 & 2.10 \\
Salicylic & 1.32 & 2.87 & 2.65 & 1.32 & 2.26 \\
Ascorbic & 1.76 & 2.10 & 2.21 & 1.10 & 1.71 \\
Mean & 1.45 & 2.25 & 2.21 & 2.21 & 2.07 \\
\hline & & 2.25 & 1.72 & \\
Control & 0.44 & 0.52 & $\mathbf{P ( \% )}$ & & \\
Moringa & 0.32 & 0.65 & 0.25 & 0.24 & 0.36 \\
K2 $\mathbf{O}_{3} \mathbf{S i}$ & 0.36 & 0.47 & 0.46 & 0.33 & 0.42 \\
Salicylic & 0.43 & 0.43 & 0.30 & 0.44 & 0.43 \\
Ascorbic & 0.22 & 0.54 & 0.24 & 0.25 & 0.35 \\
Mean & 0.35 & 0.52 & 0.33 & 0.22 & 0.31 \\
\hline & & & 0.30 & \\
Control & 1.66 & 1.86 & 1.95 & & \\
Moringa & 1.75 & 2.01 & 1.89 & 1.72 & 1.80 \\
K2 $\mathbf{O}_{3} \mathbf{S i}$ & 2.04 & 1.95 & 1.72 & 1.86 & 1.88 \\
Salicylic & 1.46 & 1.86 & 1.86 & 1.52 & 1.81 \\
Ascorbic & 1.75 & 1.72 & 1.69 & 1.81 & 1.75 \\
Mean & 1.73 & 1.88 & 1.82 & 1.55 & 1.68 \\
\hline
\end{tabular}

Plants watered at 3 weeks interval and treated with ascorbic acid had the highest total carbohydrate\%, while those watered at 1 week interval and treated with salicylic acid besides the untreated control plants had the lowest record in the same regard.

\section{b. Total chlorophyll content (mg/g f.w.):}

Watering plants at 2 weeks interval induced the highest total chlorophyll content, while watering at 4 weeks interval resulted in the lowest content in the same regard.

Applying ascorbic acid gave rise to the highest value of total chlorophyll content. On the other hand, plants treated with moringa extract had the lowest record in the same question.

Plants watered at 1 week interval and treated with ascorbic acid, besides those watered at 2 weeks interval and treated with either moringa extract or ascorbic acid occupied the highest position concerning total chlorophyll content, while those treated with moringa extract and watered at either 3 or 4 weeks interval occupied the lowest rank of the same character.

\section{c. Carotenoides content (mg/g f.w.):}

Watering plants at 2 weeks interval induced the highest content of carotenoides, while watering at 4 weeks interval gave rise to the lowest content in the same regard.

Applying ascorbic acid gave rise to the highest value of carotenoids content. On the other hand, plants treated with moringa extract had the lowest record in the same concern.

Plants watered at 2 weeks interval and treated with ascorbic acid had the highest rank concerning carotenoids content, while those treated with moringa extract and watered at either 3 or 4 weeks interval occupied the lowest position of the same character. 
Table 6. Effect of irrigation intervals, bio and chemical treatments and their interaction on carbohydrates and pigments content of Euphorbia milii var. longifolia.

\begin{tabular}{|c|c|c|c|c|c|}
\hline \multirow{2}{*}{ Treat. } & \multicolumn{5}{|c|}{ Irrigation intervals (weeks) } \\
\hline & 1 & 2 & 3 & 4 & Mean \\
\hline & \multicolumn{5}{|c|}{ Total carbohydrates (\%) } \\
\hline Control & 7.36 & 11.33 & 25.80 & 15.19 & 14.92 \\
\hline Moringa & 13.77 & 12.59 & 11.92 & 8.30 & 11.65 \\
\hline $\mathbf{K}_{2} \mathbf{O}_{3} \mathbf{S i}$ & 9.75 & 10.21 & 12.93 & 20.38 & 13.32 \\
\hline Salicylic & 7.17 & 8.79 & 23.36 & 18.40 & 14.43 \\
\hline Ascorbic & 13.00 & 31.14 & 30.61 & 18.58 & 23.33 \\
\hline \multirow[t]{2}{*}{ Mean } & 10.21 & 14.81 & 20.92 & 16.17 & \\
\hline & \multicolumn{5}{|c|}{ Total chlorophylls (mg/g f.w.) } \\
\hline Control & 0.92 & 1.15 & 1.03 & 0.33 & 0.86 \\
\hline Moringa & 1.26 & 1.53 & 0.25 & 0.23 & 0.82 \\
\hline $\mathrm{K}_{2} \mathrm{O}_{3} \mathrm{Si}$ & 0.67 & 0.79 & 0.94 & 0.94 & 0.84 \\
\hline Salicylic & 0.84 & 0.84 & 1.46 & 1.18 & 1.08 \\
\hline Ascorbic & 1.54 & 1.52 & 1.25 & 0.88 & 1.30 \\
\hline \multirow[t]{2}{*}{ Mean } & 1.05 & 1.17 & 0.99 & 0.71 & \\
\hline & \multicolumn{5}{|c|}{ Carotenoids (mg/g f.w.) } \\
\hline Control & 61.26 & 69.63 & 64.82 & 23.00 & 54.68 \\
\hline Moringa & 64.04 & 72.65 & 18.43 & 16.31 & 42.86 \\
\hline $\mathrm{K}_{2} \mathbf{O}_{3} \mathrm{Si}$ & 47.87 & 51.00 & 60.82 & 64.03 & 55.93 \\
\hline Salicylic & 57.38 & 58.61 & 76.76 & 83.31 & 69.02 \\
\hline Ascorbic & 80.59 & 87.17 & 67.94 & 61.21 & 74.23 \\
\hline Mean & 62.23 & 67.81 & 57.75 & 49.57 & \\
\hline
\end{tabular}

\section{DISCUSSION}

Our findings are in accordance with those of a lot of authors in most cases in different aspects of this work, with few exceptions that might be on the contrary.

For irrigation intervals, a lot of conflicting arguments could be found in the literature dealing with irrigation. Some researchers claimed that higher levels of irrigation are in favor of plant height. Dickey et al. (1963) declared that 'Formosa' azalea plants watered every 3 and 6 days were larger than those watered every day. There was little difference in growth of Viburnum suspensum plants watered every 1 or 3 days, and both produced larger plants than ones watered every 6 days. As watering frequency decreased from every day to every 3 and 6 days, $\mathrm{N}$ increased, Ca decreased and $\mathrm{P}, \mathrm{K}$ and $\mathrm{Mg}$ showed no change in the leaf tissue. Hussein and Donald (1974), Mustafa and
Magid (1982) and Amin, (1988) reported that plant height, number of leaves per plant, leaf area, fresh and dry weight of Sorghum bicolor increased with decreasing irrigation interval. Kabbashi, (1991) working on the same plant mentioned that shorter irrigation intervals $(10,15$ days) resulted in higher yields than longer (20 days) irrigation intervals. Musa (2003) stated that watering interval had significant effect on plant height and leaf area of Sorghum bicolor. Frequent irrigation interval (7 days) improved growth attributes and dry matter production. Khan et al. (2005) observed that 5 days irrigation interval was better compared to other intervals in relation to plant growth. The maximum plant height and number of leaves/plant were significantly better in 5 days irrigation intervals than 10, 15 and 20 days intervals in two onion varieties. Ismail et al. Ozawa (2009) studied the effect of irrigation interval (1, 3 and 5 day) on Chile 
pepper. They indicated that increasing the water supply caused increases in the root biomass. The 1-day irrigation interval produced the highest root biomass, while the 5-day resulted in the least root biomass and caused a reduction in leaf growth. El-Naim et al. (2010) found that frequent irrigation intervals (7 days) improved vegetative growth, i.e. plant height, stem diameter, number of leaves per plant, leaf area and shoot dry weight of sunflower.

Ademilua (2013) stated that Acalypha wilkesiana plants watered daily had higher plant height, larger leaf areas, fresh weight and dry weights than those watered every three days. El-Mekawy (2013) on Achillea santolina showed that irrigation every 7 days increased number of branches/plant, plant height, fresh and dry weight of herb/plant, fresh and dry weight of roots/plant compared to irrigation every 14 and 21 days.

Adeoye et al. (2014) showed that irrigation interval has little effect on stem height and leaf number of bell pepper (Capsicum annuum). The tallest plant was observed in the 3 days irrigation interval, while the control un-irrigated plot has the least height. Daily irrigation interval shows the maximum leaf number and control plot recorded the least leaf number. Leaf area was highest in plot with 6 days irrigation interval and minimum leaf area was recorded in the control plot. Bostan et al. (2014) observed that leaf length, leaf width and number of leaves/plant were maximum at irrigation interval of 10 days compared to 5, 15 and 20 days intervals. Mohamed et al. (2014) investigated the influence of irrigation intervals (every 1,2 or 3 weeks) on the growth of both Curcuma aromatica and $C$. domestica plants. They found that the long irrigation intervals significantly reduced growth parameters (plant height, number of leaves, width of the leaf). Growth parameters, as well as total carbohydrate increased when the plants irrigated every week, compared to irrigation treatments every two or three weeks. Taweesak et al. (2014) concluded that the increment of irrigation frequencies can improve growth and flowering of Chrysanthemum morifolium.

Gerami et al. (2016) stated that there were significant effects of irrigation intervals on measured morphological traits of oregano (Origanum vulgare). Plant height, leaf area, fresh and dry herb yield declined with increasing irrigation intervals, while number of branches was not influenced. The highest values were obtained under 1 week interval and the minimum values for these traits were observed under 2 or 3 weeks interval, with no significant difference between them.

Increasing irrigation intervals means decreasing watering amount along a certain period of time. This reduction in watering had a negative result on most traits as mentioned by many researchers. Tucker and Maciarello (1994) found that water stress has negative effect on biomass in oregano (Origanum vulgare). Schuch (1998) reported that for chrysanthemum, reduction of irrigation from sufficient to deficient decreased its growth by $25 \%$.

Hsiao and Xu (2000) reported that under water deficiency, growth is readily inhibited and growth of roots is favoured over that of leaves. Baeck et al. (2001) noticed that plant growth of Ocimum americanum decreased in response to water deficit. Singh-Sangwan et al. (2001) Supported that water supply is an important factor affecting growth and metabolic activities in plant species. Water deficit has generally negative effect on plant growth and development. However, there are reports on the positive effect of limited water supply, as far as the biosynthesis of secondary metabolites, enzyme activities and solute accumulation is concerned.

Guoxiong et al. (2002) mentioned that extensive root growth is an adaptive feature under drought stressed conditions. Albouchi et al. (2003) added that in order to increase absorption of water, plants in water deficit conditions often reduce their biomass production and contribute more biomass to roots. Hassani (2006) revealed that plant 
height, number and length of axiliary shoots, fresh and dry herb yield of Dracocephalum moldavica declined with decreasing soil water content.

Emmanuel (2014) stated that total biomass and root dry weights of Picralima nitida, (Apocynaceae) seedlings were lower in both water stressed and water logging conditions than well-watered conditions; but the lowest values were obtained under waterlogging. However, leaf area was higher in water-stressed conditions than wellwatered conditions. He concluded that Picralima nitida can be raised with some satisfactory growth under some form of water stress but cannot grow well in flooding conditions.

Regarding positive effect of moringa extract, Asres (1995), Anwar and Bhanger (2003), Bennett et al. (2003) and Emongor (2012) claimed that moringa leaves contain proteins, minerals, vitamins, essential amino acids, glucosinolates, isothiocyanates and phenolics. Hall et al. (1982) on Helianthus annuus reported that applying moringa leaves extract stimulated plant growth. Fuglie (2000 a and b) remarked that leaf extracts of Moringa oleifera have been reported to accelerate growth of young plants, strengthen plants, increase leaf area duration, increase number of roots, produce more and larger fruits and generally increase yield by 20 to 35\%. Andrews (2006) and Price (2007) mentioned that the active growth enhancing substances in Moringa leaf extract are reported to be zeatin, dihydrozeatin and isopentyladenine which are natural (endogenous) cytokinins. Price (2007) stated that extracts from fresh Moringa leaves could be used to produce an effective plant growth enhancer, increasing growth by $25-30 \%$ for nearly any crop. Mvumi et al. (2013) found that moringa extract increased growth and yield of beans in both greenhouse and field, and of maize in the field. However, the extract showed no significant effect on root dry weight or plant height of maize in the greenhouse. Bashir et al. (2014) noticed that moringa leaf extract increased the growth of tomato plants significantly. Emongor (2015) showed that Moringa leaf extract applied to snap bean plants (Phaseolus vulgaris) at at 20-30\% increased vegetative growth, leaf chlorophyll content,and plant dry matter (shoot and root).

On the other hand this study emphasized the positive effect of ascorbic acid specialy under stress. In this regard Abd El-Aziz et al. (2006) reported that salinity treatments on Khaya senegalensis have a depressing effect on various growth parameters (i.e. stem length, root length, leaves number/plant, leaf area and fresh and dry weight of all plant organs, total sugar, chlorophyll and carotenoids content as well as the percentage of $\mathrm{N}, \mathrm{P}$ and $\mathrm{K}$ ). However, all previous parameters tended to increase by applying ascorbic acid at $400 \mathrm{mg} / \mathrm{l}$. Farahat et al. (2007) reported that pronounced increases in vegetative growth and chemical constituents of Cupressus semprvirens plants were observed by foliar application of ascorbic acid at $40 \mathrm{mg} / \mathrm{l}$.

Mazher et al. (2011) showed that ascorbic acid at $200 \mathrm{mg} / \mathrm{l}$ increased all growth parameters (plant height, number of branches, number of leaves, root length as well as fresh and dry weights of all organs and also the content of the total carbohydrates, percentages of N, P and K) of Codiaeum variegatum plant. Khafagy et al. (2013) found that ascorbic acid (AsA) at 100 $\mathrm{mg} / \mathrm{l}$ could partially alleviate the harmful effect of salinity stress on plant growth and biochemical constituents of hibiscus plants. Most criteria of plant growth (shoot height, number of branches, number of leaves, leaf area, root length as well as fresh and dry weights of shoots and roots) significantly increased by application of ascorbic acid. AsA increased photosynthetic pigments, total soluble sugars, $\mathrm{N}, \mathrm{P}$ and $\mathrm{K}$ percentages.

Sardoei et al. (2014) showed that ascorbic acid at $20 \mathrm{mg} / \mathrm{l}$ had positive effect on number of flowers/plant of Gazania rigens cv. Daybreak Red Stripe. Sofy et al. (2016) stated that treating Chenopodium quinoa plants with ascorbic acid at $50 \mathrm{mg} / \mathrm{l}$ 
caused significant increases in most of the growth characteristics (lengths of shoots and roots, number of branches/plant, number of leaves/plant, plant biomass, and the contents of photosynthetic pigments and soluble carbohydrates).

Also, salicylic acid (SA) has a remarkable influence on plant physiology as mentioned by some authors. Khan et al. (2003) and Yildirim et al. (2008) indicated that exogenous SA treatment stimulated root formation and increased mineral uptake by corn, soybean and cucumber plants. Abd El-Razek et al. (2013) indicated that foliar spray of salicylic acid at $0.04 \mathrm{mg} / \mathrm{l}$ one month before beginning of flowering stage increased flowering\% and density of "Egazy Shami" olive trees.

Concerning the impact of salicylic acid on photosynthetic pigments, Gunes et al. (2007) attributed the positive effect of SA to enhanced $\mathrm{CO}_{2}$ assimilation, active $\mathrm{Fe}$ content, chlorophyll concentration, and photosynthetic rate, which protect photosynthesis system. Kazemi et al. (2010) mentioned that foliar application of SA to plants significantly enhanced the chlorophyll content in young leaves. This phenomenon may be attributed to the fact that foliar application of SA decreased chlorophyll degradation caused by senescence and environmental stress. This effect on chlorophyll content might also be interpreted by the work of Kong et al. (2014) who indicated that SA acts as plant growth regulator that can effectively reduce the adverse effect on amylase activity, increase the activities of antioxidant enzymes, alleviate chlorosis and oxidative damage induced by Fe deficiency, as SA increased the uptake and translocation of $\mathrm{Fe}$, promoted the activation of $\mathrm{Fe}$ in the leaves of peanut, resulting in increased chlorophyll content and improved seedling growth.

\section{Conclusion:}

The best results were obtained when watering plants at 2 weeks interval combined with using either moringa extract or ascorbic acid.

\section{REFERENCES}

Abd El-Aziz, N.G.; Mazher, A.A.M. and ElHabba, E. (2006). Effect of foliar spraying with ascorbic acid on growth and chemical constituents of Khaya senegalensis grown under salt condition. American-Eurasian J. Agric. \& Environ. Sci., 1(3):207-214.

Abd El-Aziz, N.G.; Taha, L.S. and Ibrahim, S.M.M. (2009). Some studies on the effect of putrescine, ascorbic acid and thiamine on growth, flowering and some chemical constituents of Gladiolus plants at Nubaria. Ozeam J. Appl. Sci., 2(2):169-179.

Abd El-Razek, E.; Hassan, H.S.A. and Gamal El-Din, K.M. (2013). Effect of foliar application with salicylic acid, benzyladenine and gibberellic acid on flowering, yield and fruit quality of olive trees (Olea europaea L.). Middle-East J. Sci. Res., 14(11):1401-1406.

Ademilua, A.; Omobolanle, E. and Chinonye, M.G. (2013). Effect of different water regimes on the growth and phytochemical constituents of Acalypha wilkesiana harvested at 3 am and $3 \mathrm{pm}$. Intl. J. Sci. and Nature, 4(4):619-623.

Adeoye, P.A.; Adesiji, R.A.; Oloruntade, A.J. and Njemanze, C.F. (2014). Effect of irrigation intervals on growth and yield of bell pepper (Capsicum annuum) in a tropical semi-arid region. Amer. J. Exp. Agric., 4(5):515-524.

Albouchi, A.; Bejaoui, Z. and El-Aouni, M.H. (2003). Influence of moderate or severe water stress on the growth of Casuarina glauca Sieb. seedlings. Secheresse, 14:137-142.

Amin, H.S. (1988). Effect of Water Stress on Some Physiological Aspects, Growth and Yield of Sorghum (Sorghum bicolor (L) 
Moench). M.Sc. Thesis, Sambat, Fac. Agric., Univ. Khartoum, Sudan.

Andrews, D. (2006). Nutraceutical moringa composition. InterNet Site: http://www.google.com/patents/US20060 222882/

Anwar, F. and Bhanger, M.I. (2003). Analytical characterization of Moringa oleifera Lam seed oil grown in temperate regions of Pakistan. J. Agric. and Food Chem., 51:6558-6563.

Arrigoni, O. and De Tullio, M.C. (2000). The role of ascorbic acid in cell metabolism: between gene-directed functions and unpredictable chemical reactions. J. Plant Physiol. 157:481-488.

Arrigoni, O. and De Tullio, M.C. (2002). Ascorbic acid: much more than just an antioxidant. Biochimica et Biophysica Acta, 1569:1-9.

Asres, K. (1995). The major constituents of acetone fraction of Ethiopian Moringa stenopetala L. leaves. Mansoura J. Pharma. Sci., 11(1):55-64.

Baeck, H.; Kuenwoo, P.; Baeck, H.W. and Park, K.W. (2001). Effect of watering on growth and oil content of sweet basil (Ocimum americanum L.). Korean J. Hort. Sci. Tech. 19:81-86.

Barth, C.M.; De Tullio, M.C. and Conklin, P.L. (2006). The role of ascorbic acid in the control of flowering time and the onset of senescence. J. Exper. Bot., 57:1657-1665.

Bashir, K.A.; Bawa, J.A. and Mohammed, I. (2014). Efficacy of leaf extract of drumstick tree (Moringa oleifera Lam.) On the growth of local tomato (Lycopersicon esculentum). IOSR J. Pharma. and Biol. Sci., 9(4/I):74-79.

Bennett, R.N.; Mellon, F.A.; Foidl, N.; Pratt, J.H.; DuPont, M.S.; Perkins, L. and Kroon, P.A. (2003). Profiling glucosinolates and phenolics in vegetative and reproductive tissues of the multipurpose trees Moringa oleifera Lam (horse radish) and Moringa stenopetala L. J. Agric. and Food Chem., 51:35463553.

Bostan, N.; Sajid, M.; Wahid, F.; Rabi, F.; Qureshi, S.; Ahmad, W.; Ahmad, S. and Tawab, S. (2014). Effects of growing media and irrigation interval on growth of amaryllis (Hippeastrum belladonna). Adv. in Life Sci. and Tech., 18:20-27.

Cavins, T.; Marek, S. and Kamenidou, S. (2010). InterNet Site http://www.greenhousemag.com/article/g mpro-0610-silicon-plant-growth/

Datnoff, L.E.; Rodrigues, F.A. and Seebold, K. (2007). Silicon and Plant Disease. In: Datnoff, L.E.; W.H. Elmer and D.M. Huber (Eds.). Mineral Nutrition and Plant Disease. St. Paul: The Amer. Phytopathol. Soc., 233-246.

De Tullio, M.C; Paciolla, C.; Vecchia, F.D.; Rascio, N.; D’Emerico, S.; De Gara, L.; Liso, R. and Arrigoni, O. (1999). Changes in onion root development induced by the inhibition of peptidylproyl hydroxylase and influence of the ascorbate system on cell division and elongation. Planta, 209:424-434.

Dickey, R.D.; Poole, R.T. and Joiner, J.N. (1963). Effect of watering frequencies, time and rate of fertilization on growth and chemical composition of Rhododendron indicum 'Formosa' and Viburnum suspensum. Florida Agric. Exp. St. J. Series, 1776:431-436.

Duncan, D.B. (1955) Multiple range and multiple $\mathrm{F}$ tests. Biometrics. Intl. Biometric Soc., 11(1):1-42.

El-Awady, A. (2003). Moringa Tree: Nature's Phamarcy. InterNet Site http://archive.islamonline.net/?p=15609

El-Kobisy, D.S.; Kady, K.A.; Hedani, R.A. and Agamy, R.A. (2005). Response of pea plant (Pisum sativum) to treatment with ascorbic acid, Egypt. J. Appl. Sci., 20:36-50. 
El-Naim, A.M.; Mahmoud, F. and Ahmed, A. (2010). Effect of Irrigation Intervals and Inter-row spacing on the vegetative growth characteristics on sunflower (Helianthus annuus L.) hybrids in shombat soil. J. App. Res., 6(9):14401445.

Emmanuel, G.A. (2014). Effect of watering regimes and water quantity on the early seedling growth of Picralima nitida (Stapf). Sustainable Agric. Res., 3(2):3543.

Emongor (2012). Guidelines on good agricultural practices in the production of moringa (Moringa oleifera Lam). Scripta Hortic., 15:115-132.

Emongor, V.E. (2015). Effects of Moringa (Moringa oleifera) leaf extract on growth, yield and yield components of snap beans (Phaseolus vulgaris). British J. Appl. Sci. Tech., 6(2):114-122.

Farahat, M.M.; Ibrahim, S.M.M.; Taha, L.S. and El-Quesni, F.E.M. (2007). Response of vegetative growth and some chemical constituents of Cupressus sempervirens L. to foliar application of ascorbic acid and zinc at Nubaria. World J. Agric. Sci., 3(3):282-288.

Fuglie, L.J. (2000 a). New Uses of Moringa Studied in Nicaragua: ECHO's Technical Network Site-networking global hunger solutions. ECHO, Nicaragua, p. 1-7.

Fuglie, L.J. (2000 b). The Miracle Tree: Moringa oleifera: Natural Nutrition for the Tropics. Lowell J. Fuglie, CTA, Wageningen, Netherlands, 172 pp.

Gerami, F.; Moghaddam, P.R.; Ghorbani, R. and Hassani, A. (2016). Effects of irrigation intervals and organic manure on morphological traits, essential oil content and yield of oregano (Origanum vulgare L.). Anais da Academia Brasileira de Ciências, 88(4):2375-2385.

Gest, N.; Gautier, H. and Stevens, R. (2013). Ascorbate as seen through plant evolution: the rise of a successful molecule. J. Exp. Bot., 64:33-53.
Gunes, A.; Inal, A.; Alpaslan, M.; Eraslan, F.; Bagci, E.G. and Cicek, N. (2007). Salicylic acid induced changes on some physiological parameters symptomatic for oxidative stress and mineral nutrition in maize (Zea mays L.) grown under salinity. J. Plant Physiol., 164:728-736.

Guoxiong, C.; Krugman, T.; Fahima, T.; Korol, A.B. and Nevo, E. (2002). Comparative study on morphological and physiological traits related to drought resistance between xeric and mesic Hordeum spontaneum lines in Israel. Barley Genet. Newslett., 32:22-33.

Hall, A.B.; Blum, U. and Fites, R.C. (1982). Stress modification of allelopathy of Helianthus annuus L. debris on seed germination. Amer. J. Bot., 69:776-783.

Hartmann, T.; College, M. and Lumsden, P. (2005). Responses of different varieties of Lolium perenne to salinity. Annual Conf. Soc. for Exp. Biol., Lancashire.,104:71-78.

Hassani, A. (2006). Effect of water deficit stress on growth, yield and essential oil content of Dracocephalum moldavica. Iran J. Med. Arom. Pl., 22:256-261.

Herbert, D.; Philips, P.J. and. Strange, R.E. (1971). Determination of total carbohydrates. Methods in MicroBiol., 58:209-344.

Hsiao, T.C. and Xu, L. (2000). Sensitivity of growth of roots versus leaves to water stress: biophysical analysis and relation to water transport. J. Exp. Botany, 51(350):1595-1616.

Hussein, M.M. and W.B. Donald (1974). Effect of irrigation frequencies and nitrogen rates on the growth of forage sorghum. Agric., Pakistan, 25(3):159164.

InterNet $\quad$ Site 1 (2017): https://en.wikipedia.org/wiki/Euphorbia_ milii

Ismail, S.M. and Ozawa, K. (2009). Effect of irrigation Interval on growth 


\section{Azza M. Abd-Elmoneim et al.}

characteristics, plant water stress tolerance and water use efficiency for Chile pepper. Thirteenth Intl. Water Tech. Conf., Hurghada, Egypt, 545-556.

Jackson, M.J. (1973). Soil Chemical Analysis. Prentice Hall of India Private, New Delhi.

Kabbashi, B.A. (1991). Effect of Irrigation Intervals on and Seasonal Variation on Growth and Yield of Sorghum bicolor (var. Abu 70). M.Sc. Thesis, Fac. Agric., Univ. Khartoum, Sudan.

Kazemi, N.; Khavari-Nejad, R.A.; Fahimi, H.; Saadatmand, S. and Nejad-Sattari, T. (2010). Effects of exogenous salicylic acid and nitric oxide on lipid peroxidation and antioxidant enzyme activities in leaves of Brassica napus L. under nickel stress. Sci. Hort., 126:402407.

Khafagy, M.A.; Abdalla, M.Y.A.; Hussein, H.A.A. and Ahmed, S.A.M. (2013). Response of Hibiscus rosa-sinensis L. to the interactive effect of seawater salinity and ascorbic acid. J. Plant Production, Mansoura Univ., 4(1):51-78.

Khan, M.H.; Imran, M. and Chattha, T.H. (2005). Effect of Irrigation Intervals on Growth and Yield of onion varieties Swat-1 and Phulkara. J. Appl. Sci. Res., 1(2):112-116.

Khan, W.; Prithiviraj, B. and Smith, D.L. (2003). Photosynthetic responses of corn and soybean to foliar application of salicylates. J. Plant Physiol., 160:485492.

Kong, J.; Dong, Y.; Xu, L.; Liu, S. and Bai, X. (2014). Effects of foliar application of salicylic acid and nitric oxide in alleviating iron deficiency induced chlorosis of Arachis hypogaea $L$. Botanical Studies, 55:9.

Liu, W.; Hu, W.Y.; Hao, J.J. and Chen, G. (1997). The relationship between ascorbic acid and changes of several physiological and biochemical indexes in isolated wheal leaves under $\mathrm{NaCl}$ stress.
Plant Physiol. Communications, 33(6): 423-425.

Mattson, N.S. and Leatherwood, W.R. (2010). Potassium silicate drenches increase leaf silicon content and affect morphological traits of several floriculture crops grown in a peat-based substrate. Hortscience, 45(1):43-47.

Mazher, A.A.M.; Zaghloul, S.M.; Mahmoud, S.A. and Siam, H.S. (2011). Stimulatory effect of kinetin, ascorbic acid and glutamic acid on growth and chemical constituents of Codiaeum variegatum L. plants. Amer.-Eurasian J. Agric. \& Environ. Sci., 10(3):318-323.

Mohamed, M.A.; Wahba, H.E.; Ibrahim, M.E. and Yousef, A.A. (2014). Effect of irrigation intervals on growth and chemical composition of some Curcuma spp. Plants. Nusantara Bioscience, 6(2):140-145.

Musa, B.E.E. (2003). Effect of Watering Interval and Nitrogen Application on Growth and Yield of Fodder Sorghum (Sorghum bicolor L. Moench). M.Sc. Thesis, Fac. Agric., University of Khartoum, Sudan.

Mustafa, H.A. and Magid, E.A. (1982). Interrelation of irrigation frequency, urea nitrogen, and gypsum on forage sorghum growth on a saline sodic clay soil. Agronomy J., 74:447-451.

Mvumi, C.; Tagwira, F. and Chiteka, A.Z. (2013). Effect of moringa extract on growth and yield of maize and common beans. Greener J. Agric. Sci., 3(1):55-62.

Noctor, G. and Foyer, C.H. (1998). Ascorbate and glutathione: keeping active oxygen under control. Annu. Rev. Plant Physiol. Plant Mol. Biol., 49:249279.

Pignocchi, C. and Foyer, C.H. (2003). Apoplastic ascorbate metabolism and its role in the regulation of cell signalling. Current Opinion in Pl. Biol., 6:379-389. 
Price, M. (2007). The Moringa tree. ECHO Technical Note, ebook.

Reda, F; Abdel-Rahim, E.A.; El-baroty, G.S.A. and Ayad, H.S. (2005). Response of essential oil, phenolic components and polyphenol oxidative activity of Thyme (Thymus vulgaris L.) to some bioregulators and vitamins. Int. J. Agric. Biol., 7(5):735-739.

Sardoei, A.S.; Shahdadneghad, M.; Monir R.Y. and Mohammadi, T. (2014). Effects of zinc sulphate and ascorbic acid on flowering characteristics of ornamental plant Gazania (Gazania rigens) cv. Daybreak Red Stripe. Intl. J. Adv. Biol. and Biomed. Res., 2(2):392-398.

Saric, M.; Kastrori, R.; Curie, R.; Cupina, T. and Gerie, I. (1976) Chlorophyll determination. Univ. U. Noven Sadu Praktikum is Kiziologize Bilijaka, Beogard, Hauncna, Anjiga, p. 215.

Schuch, U.K. (1998). Cultivar, fertilizer and irrigation affect vegetative growth and susceptibility of chrysanthemum to western flower thrips. J. Amer. Soc. Hort. Sci., 123(4):727-733.

Singh-Sangwan, N.; Farrooqi, A.H.A.; Shabih, F. and Sangwan, R.S. (2001). Resultation of essential oil production in plants. Plant Growth Reg. 34:3-21.

Smirnoff, N. and Wheeler, G.L. (2000). Ascorbic acid in plants: biosynthesis and function. Critical Reviews in Biochem. and Molec. Biol., 35:291-314.

Snedecor, C.W. and Cochran, W.G. (1989) Two-way classification, Analysis of
Variance Statistical Methods $8^{\text {th }}$ ed., Iowa State Univ. Press Ames, Iowa, U.S.A. p. 254-268.

Sofy, M.R.; Sharaf, A.M. and Foudam H.M. (2016). Stimulatory effect of hormones, vitamin $\mathrm{C}$ on growth, yield and some metabolic activities of Chenopodium quinoa plants in Egypt. J. Plant Biochem. \& Physiol., 4(1):1-10.

Taweesak, V.; Abdullah, T.L.; Hassan, S.A.; Kamarulzaman, N.H. and Yusoff, W.A.W. (2014). Growth and flowering responses of cut chrysanthemum grown under restricted root volume to irrigation frequency. Hindawi Publishing Corporation Sci. World J., pp 6.

Tucker, A.O. and Maciarello, M.J. (1994). Oregano: botany, chemistry, and cultivation. In: Charalambous, G. (Ed), Spices, Herbs and Edible Fungi. Elsevier Sci. B.V., Oxford, UK, pp 439-456.

Vicente, M.R. and Plasenciam J. (2011). Salicylic acid beyond defence: its role in plant growth and development. J. Exp. Bot., 62(10):3321-3338.

Voogt, W. and Sonneveld, C. (2001). Silicon in horticultural crops grown in soilless culture. Stud. Plant Sci., 8:115-131.

Yildirim, E.; Turan, M. and Guvenc, I. (2008). Effect of foliar salicylic acid applications on growth, chlorophyll and mineral content of cucumber (Cucumis sativus L.) grown under salt stress. J. Plant Nutr., 31:593-612.

\section{أثر نظام الرى وبعض المعاملات على نباتات إيوفوربيا ميلياى لونجيفوليا المزهرة (تاج الاشواك)

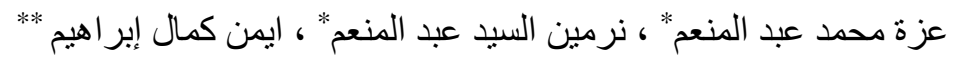

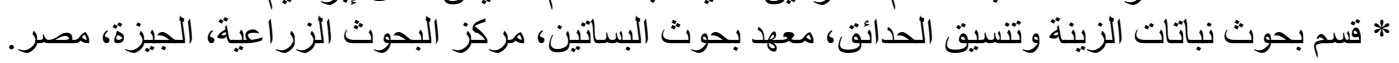

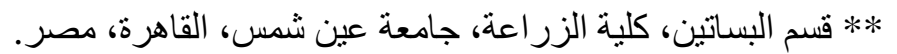

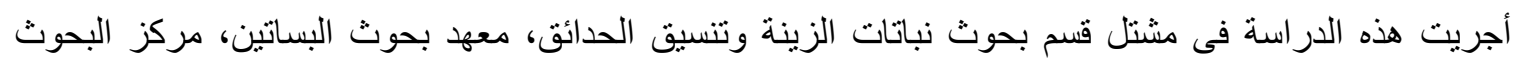

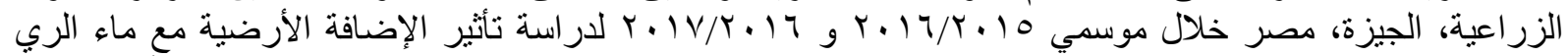

لبعض المواد الحيوية والكيميائية (مستخلص المورينجا، سليكات البوتاسيوم، حمض الساليسيلك و حمض الإنيات الأسكوربيك) 


\section{Azza M. Abd-Elmoneim et al.}

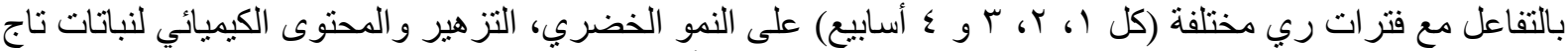

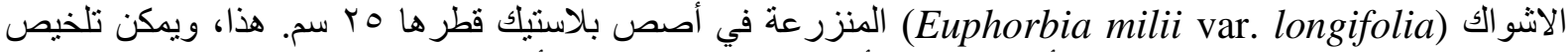

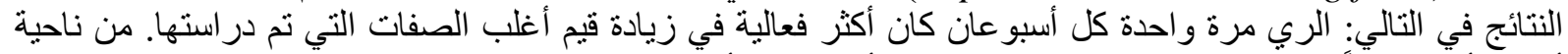

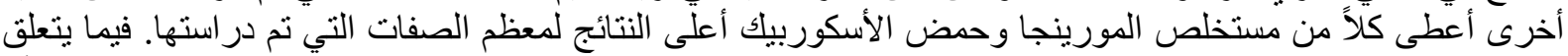

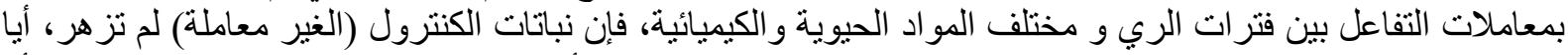

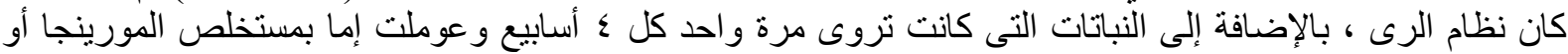

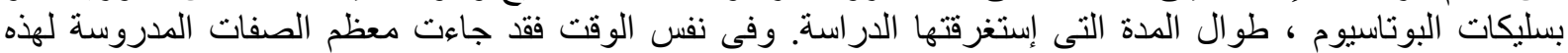

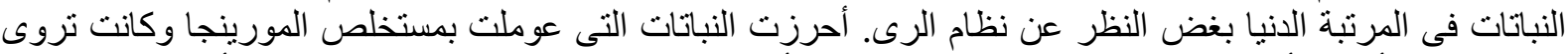

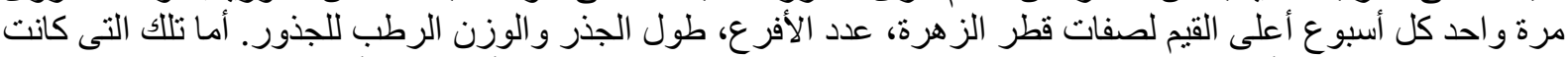

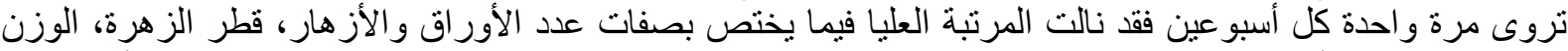

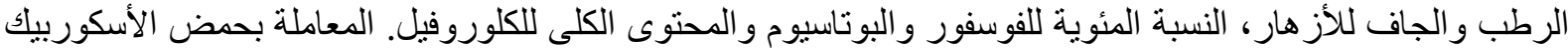

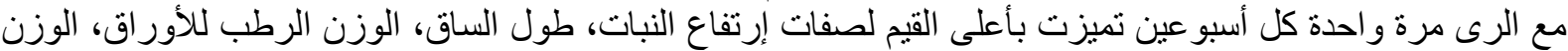

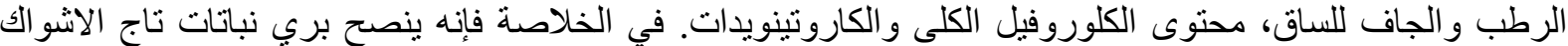

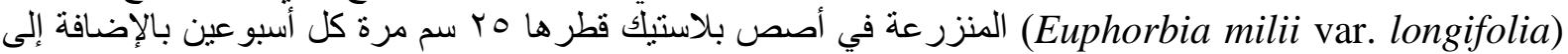
المعاملة بأي من مستخلص المورينجا أو حمض الأسكوربيك للحصول فلى على أفضل النتائج. 